\title{
The Roles of Wind and Sea Ice in Driving the Deglacial Change in the Southern Ocean Upwelling: A Modeling Study
}

\author{
Gagan Mandal ${ }^{1,2,3}$ (D) Shih-Yu Lee ${ }^{3, *}$ and Jia-Yuh Yu ${ }^{2}$ (D) \\ 1 Taiwan International Graduate Program, Earth System Science Program, Academia Sinica, \\ Taipei 11529, Taiwan; gagan.iitroorkee@gmail.com \\ 2 Department of Atmospheric Sciences, National Central University, Taoyuan 32001, Taiwan; \\ jiayuh@atm.ncu.edu.tw \\ 3 Research Center for Environmental Changes, Academia Sinica, Taipei 11529, Taiwan \\ * Correspondence: shihyu@gate.sinica.edu.tw
}

Citation: Mandal, G.; Lee, S.-Y.; Yu, J.-Y. The Roles of Wind and Sea Ice in Driving the Deglacial Change in the Southern Ocean Upwelling: A Modeling Study. Sustainability 2021, 13, 353. https://doi.org/ 10.3390/su13010353

Received: 11 November 2020 Accepted: 26 December 2020 Published: 2 January 2021

Publisher's Note: MDPI stays neutral with regard to jurisdictional clai$\mathrm{ms}$ in published maps and institutional affiliations.

Copyright: (C) 2021 by the authors. Licensee MDPI, Basel, Switzerland. This article is an open access article distributed under the terms and conditions of the Creative Commons Attribution (CC BY) license (https:// creativecommons.org/licenses/by/ $4.0 /)$.

\begin{abstract}
The Southern Ocean (SO) played a fundamental role in the deglacial climate system by exchanging carbon-rich deep ocean water with the surface. The contribution of the SO's physical mechanisms toward improving our understanding of SO upwelling's dynamical changes is developing. Here, we investigated the simulated transient SO atmosphere, ocean, and sea ice evolution during the last deglaciation in a fully coupled Earth system model. Our results showed that decreases in SO upwelling followed the weakening of the Southern Hemisphere surface westerlies, wind stress forcing, and Antarctic sea ice coverage from the Last Glacial Maximum to the Heinrich Stadial 1 and the Younger Dryas. Our results support the idea that the SO upwelling is primarily driven by wind stress forcing. However, during the onset of the Holocene, SO upwelling increased while the strength of the wind stress decreased. The Antarctic sea ice change controlled the salt and freshwater fluxes, ocean density, and buoyancy flux, thereby influencing the SO's dynamics. Our study highlighted the dynamic linkage of the Southern Hemisphere westerlies, ocean, and sea ice in the SO's latitudes. Furthermore, it emphasized that zonal wind stress forcing and buoyancy forcing control by sea ice together regulate the change in the SO upwelling.
\end{abstract}

Keywords: Southern Ocean; upwelling; sea ice; buoyancy forcing; wind stress; last deglaciation

\section{Introduction}

The last deglaciation from 21 to $9 \mathrm{kyr} \mathrm{BP}$ (before present) offers a case study for the most recent natural global warming process. This period involved a transient climate evolution from a colder to a warmer world. It was interrupted by Northern Hemisphere millennial events with a simultaneous $\mathrm{CO}_{2}$ rise that is comparable to anthropogenic emission since the industrial revolution [1]. The Southern Ocean (SO) plays a pivotal role in controlling the variation in atmospheric $\mathrm{CO}_{2}$ concentrations over glacial-interglacial cycles [2]. It ventilates a significant part of the global ocean and acts as a window for the return of carbon-rich deep ocean water to the surface. The dynamical theory of the SO dynamics is developing. Thus, understanding the physical mechanisms that determined the temporal and spatial change in SO upwelling throughout the Earth's history will improve our comprehension of the response of the $\mathrm{SO}^{\prime}$ 's dynamics in future climate projections and the associated difference in atmospheric $\mathrm{CO}_{2}$ concentrations.

During the northern Atlantic millennial events, studies show a correlation between the change in the atmospheric $\mathrm{CO}_{2}$ concentrations and Antarctic temperatures involving a poleward shift in the Southern Hemisphere mid-latitude westerlies and an increase in the SO overturning [3]. Northern Atlantic cooling during the Heinrich Stadial 1 and the Younger Dryas overlapped with the Southern Hemisphere deglacial warming, with a rise in wind-driven SO upwelling [4-9]. Thus, Northern Hemisphere stadial millennial events, 
Southern Hemisphere westerlies, and $\mathrm{SO}$ upwelling were interconnected, and an increase in SO upwelling resulted in the rise in atmospheric $\mathrm{CO}_{2}$ concentrations $[6,7,10-15]$.

The Southern Hemisphere circumpolar westerly winds cause the northward Ekman transport of SO surface waters. The northward horizontal Ekman transport results in the upwelling of deep ocean waters in the SO latitudes [16]. The Southern Hemisphere westerly wind stress [17], changes in the buoyancy fluxes due to sea ice formation and melting [18,19], and changes in the eddy fluxes [7] acting together drive the $\mathrm{SO}$ overturning circulation. The $\mathrm{SO}$ overturning circulation is dominated by two global-scale counter-rotating meridional cells [20]. The SO overturning circulation involves an upper meridional overturning cell that includes the northward Ekman transport of surface waters [21] and the southward transport of North Atlantic waters [18]. The lower meridional overturning cell comprises dense-water formation processes forming Antarctic Bottom Water around Antarctica and the northward distribution of Antarctic Bottom Water and its derivatives [12]. The surface Ekman divergence results in the $\mathrm{SO}$ overturning circulation as the sum of the Eulerian mean (wind-driven) and eddy circulations [18]. The wind-driven overturning circulation tilts the ocean density surfaces to create tilted isopycnals. It provides adiabatic pathways for the carbon-rich deep ocean water to reach the ocean's surface without involving large thermocline diffusivities [18]. The deep ocean has accumulated more respired carbon during each glacial period $[12,22,23]$ and preindustrial time. It holds a total amount of carbon that is roughly 60 times that found in the preindustrial atmosphere. Therefore, even a small change in the volume of the $\mathrm{SO}$ upwelling has the potential to alter atmospheric $\mathrm{CO}_{2}$ concentrations significantly.

Modeling results employing an idealized wind forcing have shown that an increase or poleward shift or both in zonal wind stress forcing increases the SO upwelling [3]. Paleo records $[9,14]$ and subsequent studies $[6,24-28]$ have suggested that wind stress forcing and air-sea gas exchange may account for the increase in $\mathrm{SO}$ upwelling and changes in atmospheric $\mathrm{CO}_{2}$ concentrations. However, wind-driven enhancement in the Antarctic Circumpolar Current's baroclinicity would allow for southward eddy transport (eddy saturation) [29-32]. The northward Ekman transport, as a result of the enhancement of Eulerian mean (wind-driven) overturning, could be compensated for by the intensification of opposing eddy-driven overturning (eddy compensation) [33,34]. Buoyancy forcing is altered by eddy activity such that strengthening of the zonal wind stress may increase the SO overturning rate with little change in the Antarctic Circumpolar Current transport [35-37]. Therefore, in addition to an alteration in wind stress, buoyancy forcing changes could be significant in explaining the deglacial growth in the SO upwelling.

Previous studies have suggested that the $\mathrm{SO}$ atmosphere, ocean, and sea ice are dynamically connected [38]. The SO Antarctic sea ice formation regulates the salt flux via brine rejection and freshwater flux due to summertime melting. It determines the positive (lighter ocean surface density) or negative (denser ocean surface density) ocean buoyancy flux. The presence of sea ice leads to deep ocean stratification [39], decreases the air-sea gas exchange, and impedes momentum transfer from the atmosphere onto the ocean surface [40-43]. Additionally, modeling and satellite data studies have highlighted sea ice's role in current and future climate scenarios. Recent studies have shown that the climate-induced variability in the seasonal sea ice extent and ocean stratification influences the ice-albedo feedback, thermohaline circulation, and marine primary production [44]. Therefore, it is necessary to understand the role of sea ice in the SO processes.

Earlier studies provide an understanding of the SO's dynamics. However, the role of wind stress and sea ice in the SO upwelling need additional investigations. Recently, a fully coupled Earth system climate model (TraCE-21ka) that is identical to this modeling study showed the migration of the deglacial Southern Hemisphere subtropical westerly jet as an analogy to the westerlies' circulation [45]. It is necessary to emphasize that the surface westerly wind force wind stress over the SO. Therefore, migration of the deglacial subtropical westerly jet cannot explain the change in the wind stress and SO upwelling evolution. In this study, we investigate the temporal and spatial development of the surface westerlies 
and sea ice within ocean basins moving beyond the SO's average zonal perspective. This modeling study's primary aim was to decipher, at a sub-basin scale, the role of wind stress forcing and sea ice to changes in simulated SO upwelling during the last deglaciation. We analyzed the characteristics of the surface Southern Hemisphere westerlies, SO upwelling, and the extent of the Antarctic sea ice using four millennial time snapshots during the last deglaciation. We also attempted to answer a couple of fundamental questions regarding the $\mathrm{SO}$ upwelling that linger in the paleoclimate community. These questions include: (1) How did the model simulated Southern Hemisphere surface westerlies change during four millennial time snapshots during the last deglaciation? (2) Did the change in simulated surface Southern Hemisphere westerlies explain the difference in the SO upwelling? (3) Did Antarctic sea ice influence the simulated deglacial SO upwelling?

This paper's remainder is as follows: Section 2 shows the data, model validation, and study domain. The deglacial evolution of the near-surface zonal wind, SO upwelling, zonal wind stress, and sea ice are shown in Section 3 and discussed in Section 4. Section 5 concludes this paper by stating that the role of sea ice is significant such that wind stress and sea ice together control the change in SO upwelling.

\section{Materials and Methods}

\subsection{Data}

We analyzed monthly and annual average outputs from TraCE-21ka simulations [46]. TraCE-21 ka is a fully coupled transient atmosphere-ocean-sea ice-land surface climate model experiment using the Community Climate System Model version 3 (CCSM3). The model experiment was forced with realistic transient alterations regarding the orbitally driven insolation, greenhouse gases (Figure 1a,e), meltwater fluxes from retreating ice sheets (Figure 1b,f), and continental ice sheet topography that accounted for the changing climate boundary conditions for the last $21 \mathrm{kyr}$.
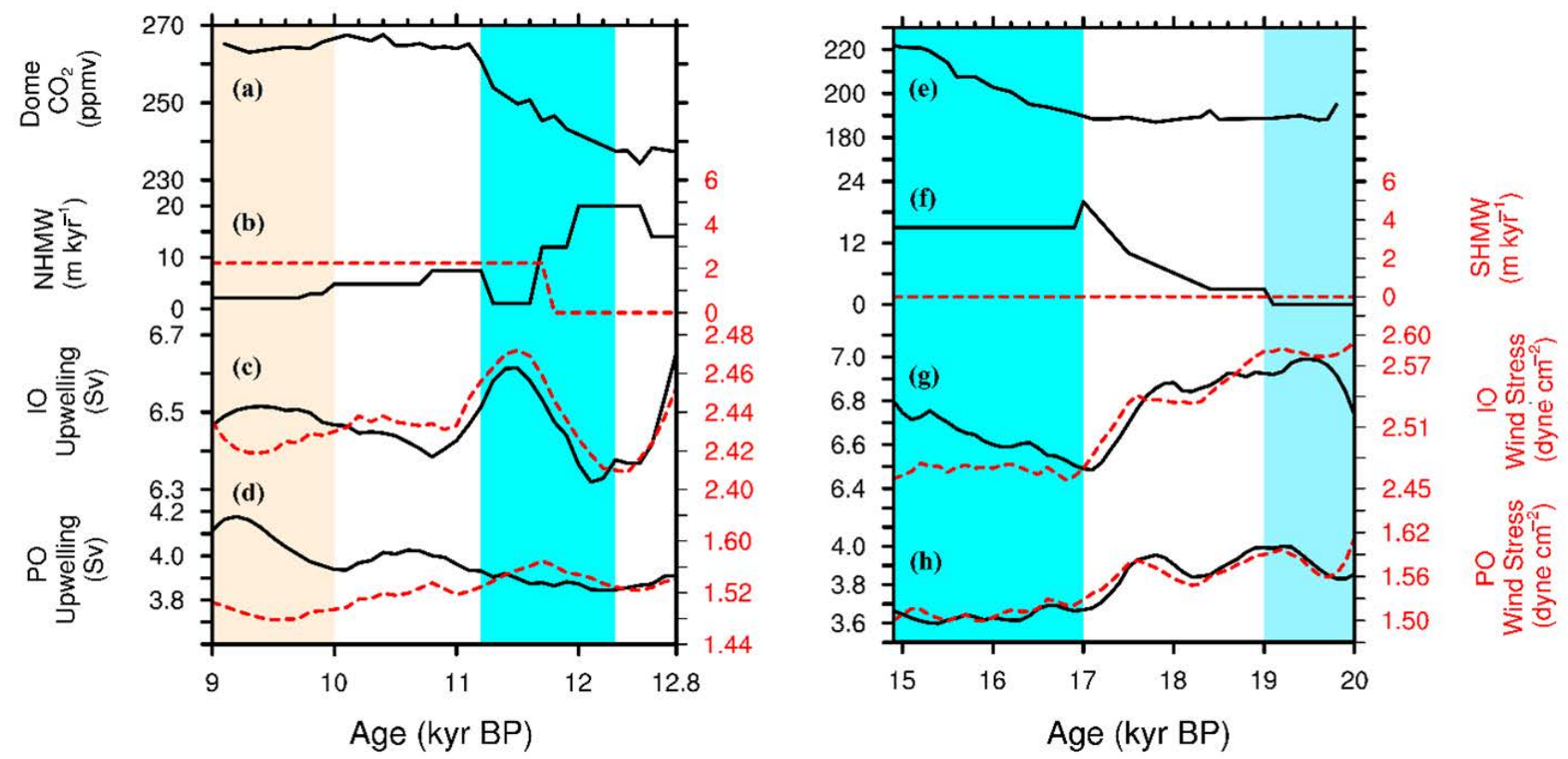

Figure 1. TraCE-21ka model simulations, meltwater forcing, and simulations from the Last Glacial Maximum (LGM) to the onset of the Holocene $\left(\mathrm{O} \_\mathrm{H}\right)$. (a,e) Atmospheric $\mathrm{CO}_{2}$ concentrations (units are in ppmv, parts per million by volume) [11]. $(\mathbf{b}, \mathbf{f})$ Northern hemisphere meltwater (NHMW) forcing (black) and Southern Hemisphere meltwater (SHMW) forcing (red, dashed) (units are in meters per kiloyear $\left(\mathrm{m} \mathrm{kyr}^{-1}\right)$ ). Simulated upwelling (black; units are in Sverdrup (Sv)) and the maximum zonal wind stress $\left(\approx 46^{\circ} \mathrm{S}\right.$; red, dashed; units are in dyne per square centimeter (dyne $\left.\mathrm{cm}^{-2}\right)$ ) was smoothed using a Savitsky-Golay filter with a third-order polynomial convolution at the Indian Ocean (IO) (c,g) and the Pacific Ocean (PO) sector $(\mathbf{d}, \mathbf{h})$ respectively. The simulations were area-averaged over the $\mathrm{IO}$ sector $\left(42^{\circ} \mathrm{S}\right.$ to $58^{\circ} \mathrm{S}$ and $86^{\circ} \mathrm{E}$ to $\left.140^{\circ} \mathrm{E}\right)$ and the $\mathrm{PO}$ sector $\left(42^{\circ} \mathrm{S}\right.$ to $58^{\circ} \mathrm{S}$ and $157^{\circ} \mathrm{W}$ to $\left.86^{\circ} \mathrm{W}\right)$. 
The employed coupled atmospheric model was the Community Atmospheric Model 3 (CAM3) performed at a T31 ( $\approx 3.75$ degrees) resolution with a vertical resolution of 26 hybrid coordinate levels. The coupled oceanic component (Parallel Ocean Program (POP)) is in spherical polar coordinates with a dipole grid. It has a resolution of gx3v5 (about 3.6 degrees longitudinal resolution with a variable latitudinal resolution; there is a finer resolution to about 0.9 degrees near the equator), with a vertical resolution of 25 levels. The sea ice model employed was the NCAR Community Sea Ice Model (CSIM), which includes a subgrid-scale ice thickness distribution. Its resolution is identical to the POP model. The ice and ocean model outputs were gridded to a T31 resolution for consistency with the atmospheric model. The ocean model caveat was that owing to its coarse resolution, it fails to resolve ocean eddies and instead uses the Gent and McWilliams parameterization [47,48]. However, the latest studies have advocated that coarse resolution models agree with the high-resolution models [15] when simulating a realistic Antarctic Circumpolar Current and the SO overturning response to freshwater and wind stress forcing. The model output is publicly available for download from the National Center for Atmospheric Research Climate Data Gateway.

TraCE-21ka model simulations have been shown to replicate many vital features of the global climate evolution during the last deglaciation [46,49], including El Niño [50], Asian-African monsoon [51], and high-latitude temperature [52]. It also demonstrated good agreement regarding the simulated atmospheric regional surface air temperature over Antarctica, the Atlantic Meridional Ocean Circulation transport, and local sea surface temperature in the south Pacific and the SO with paleo data [53]. Additionally, TraCE$21 \mathrm{ka}$ simulations reproduced the Southern Hemisphere atmospheric circulation's general characteristics well with present-day conditions [45].

\subsection{Analyzing the Performance of the CCSM3 TraCE-21ka Model Regarding Simulating the Present-Day Southern Hemisphere Climate}

This section presents the analysis of the performance of CCSM3 TraCE-21ka when simulating the SO atmospheric and oceanic features in both the Indian Ocean (IO) and Pacific Ocean (PO) sectors with the present-day NCEP/NCAR reanalysis. The model reproduced near-surface $950 \mathrm{hPa}$ zonal wind speeds (Figure S1) with a similar seasonal pattern compared to the present-day NCEP/NCAR reanalysis [54]. Near-surface Southern Hemisphere westerly winds were strongest in the ASO (August, September, and October) season compared to the JJA (June, July, and August). In the PO sector, a 33-year (1958 to 1990) monthly mean $950 \mathrm{hPa}$ zonal wind climatology had strong spatial $(r=0.8$ and $\left.R^{2}=0.97\right)$ and ASO seasonal correlations $\left(r=0.99, R^{2}=0.81, p=0.003\right.$, and RMSE $\left.=0.2\right)$ with the NCEP reanalysis I. In the IO sector, the simulated near-surface zonal wind had a strong ASO spatial correlation $\left(r=0.92, R^{2}=0.94, p<0.05\right.$, and RMSE =0.2) with the NCEP reanalysis I (one month offset). Additionally, 70-year (1920 to 1990) annual average decadal mean sea surface temperature climatology from the TraCE-21ka POP model (Figure S2) had a strong correlation in the IO $\left(r=0.9, R^{2}=0.5\right.$, and $\left.p=0.006\right)$ and PO $\left(r=0.8, R^{2}=0.5\right.$, and $\left.p=0.05\right)$ with the National Oceanic and Atmospheric Administration (NOAA) Extended Reconstructed Sea Surface Temperature (SST) V5 [55]. Simulated sea ice and ocean temperatures throughout the SO showed reasonable agreement with the IO and PO sectors' proxy records [56]. TraCE-21ka underestimated the sea surface temperatures. Nonetheless, our evaluations support the idea that the TraCE-21ka model reproduces the general properties of the SO wind and oceanic changes in the present-day reasonably well.

\subsection{Study Domain}

To investigate the last deglacial change in the SO upwelling, we chose four millennial timescales: (1) the Last Glacial Maximum (LGM; 20 to 19 kyr BP), (2) the Heinrich Stadial 1 (H1; 17 to 16 kyr BP), (3) the Younger Dryas (YD; 12.5 to $11.5 \mathrm{kyr} \mathrm{BP}$ ), and (4) the onset of the Holocene (O_H; 10 to 9 kyr BP). These four periods illustrate Earth's transient climate evolution with changing Southern Hemisphere westerlies and sea ice history. Realistic simulation of the Antarctic Cold Reversal ( $\approx 14.5$ to $\approx 12.5 \mathrm{kyr}$ BP) has been 
a challenge for the modeling community [56]. TraCE-21ka simulates Bølling-Allerød $(\approx 14.5 \mathrm{kyr} \mathrm{BP})$ warming by varying the meltwater forcing with a sudden termination, followed by the abrupt reopening of the Northern Hemisphere and Southern Hemisphere meltwater flux (Meltwater Pulse 1-A). This massive influx of meltwater at the Ross Sea and Weddell Sea surfaces possibly strengthens the upper meridional overturning cell [19], which leads to the SO upwelling's unrealistic overshooting. Therefore, in this study, we excluded this modeling limitation of the $\mathrm{SO}$ upwelling's overestimation during the Antarctic Cold Reversal.

Unlike other modeling studies that focused on the SO average zonal perspective [7], we analyzed the $\mathrm{IO}$ and $\mathrm{PO}$ at the basin scale. To identify appropriate representative sectors, we selected sections of the IO and PO basins that overlapped with the simulated Southern Hemisphere wintertime maximum near-surface winds, as shown in Figure 2. The deepest mixed layer depths are located in the Subantarctic region equatorward to the SO upwelling zone, where the Subantarctic mode water is formed and transported equatorward [57]. These representative sectors are poleward to the simulated annual mean mixed layer depths in the SO upwelling zone (simulated negative wind stress curl), as illustrated in Figure 2. Additionally, the sectors are north of the sea ice boundary and receive freshwater and salt fluxes that are associated with the Antarctic sea ice melting and freezing. Since stronger surface zonal wind may result in stronger Eulerian mean wind-driven overturning, we examined the ASO seasonal atmospheric climatology. A limitation of our ocean and sea ice model analysis is that we used annual mean data instead of seasonal due to data availability. However, the limited available ASO monthly mean ocean model output captured the ASO season's general characteristics in the annual mean ocean output $(r \approx 0.9, p<0.05)$. The simulated $\mathrm{SO}$ upwelling volume was calculated as an average vertical velocity in the representative sectors integrated to a $500 \mathrm{~m}$ depth. We reasoned that the vertical integration to deeper ocean velocities would better represent the SO upwelling. The conclusions drawn from this study remained the same, irrespective of the study area's size and depth, as long as it overlapped with maximum surface winds. 
a) LGM

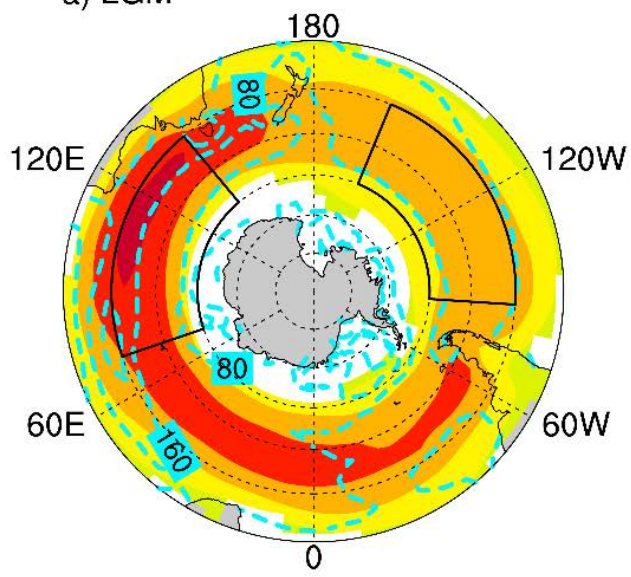

c) YD

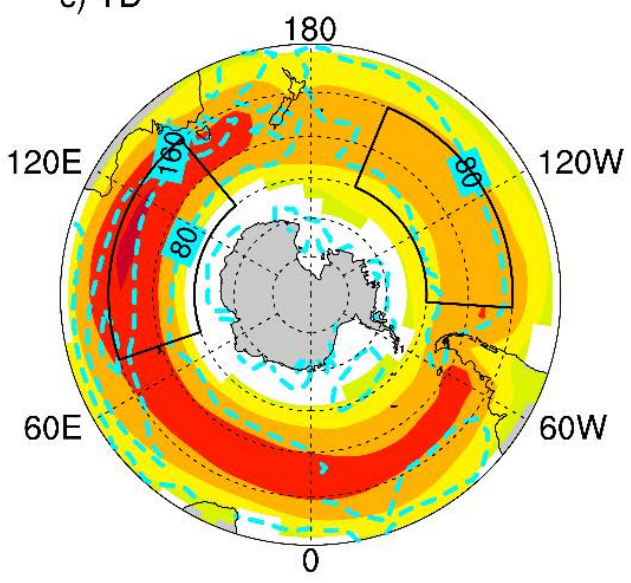

b) $\mathrm{H} 1$

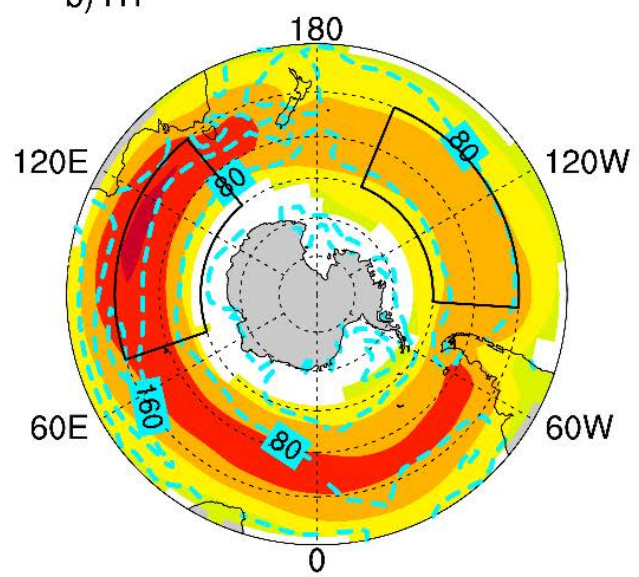

d) $\mathrm{O} \_\mathrm{H}$

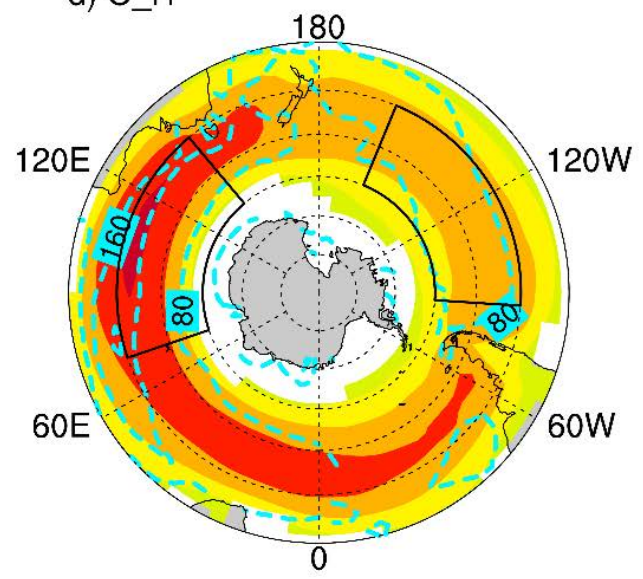

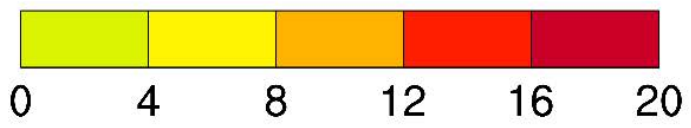

$\left(\mathrm{m} \mathrm{s}^{-1}\right)$

Figure 2. August-October (ASO) seasonal average $950 \mathrm{hPa}$ millennial mean zonal Southern Hemisphere westerly wind climatology (shaded; contour interval is $4 \mathrm{~m} \mathrm{~s}^{-1}$ ) overlain with the annual average millennial mean mixed layer depths (green, dashed; contours with a contour interval of $80 \mathrm{~m}$ ) during (a) LGM (b) H1, (c) YD, and (d) O_H, respectively. Black boxes represent the IO and PO sectors. LGM, H1, YD, and O_H represent the Last Glacial Maximum, the Heinrich Stadial 1, the Younger Dryas, and the onset of Holocene, respectively. White represents the easterly zonal wind and a lack of model values.

\section{Results}

\subsection{Zonal Wind}

Simulation of the near-surface $950 \mathrm{hPa}$ zonal wind indicated that there were strong (10 to $15 \mathrm{~m} \mathrm{~s}^{-1}$ ) winds throughout the deglaciation. The representative sectors depicted in black boxes overlapped it and lay poleward to $80 \mathrm{~m}$ annual mixed-layer depth contours (Figure 2). The simulation illustrated stronger near-surface wind and deeper yearly mixedlayer depths in the IO than the PO sector at all timescales. In particular, the model shows that the LGM had the strongest near-surface SO zonal wind ( 0.5 to $1.5 \mathrm{~m} \mathrm{~s}^{-1}$ higher) as compared to other time slices during the last deglaciation (Figure 3 ). 

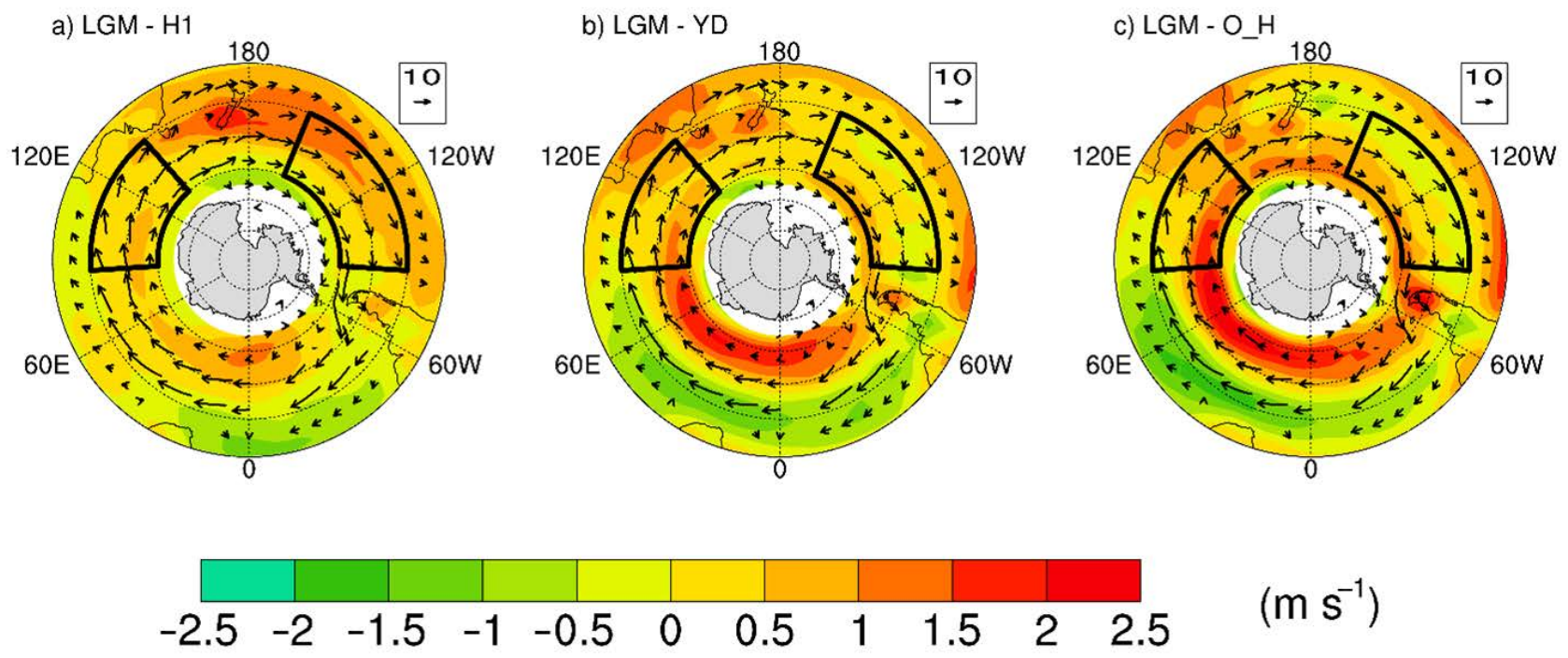

Figure 3. ASO seasonal average millennial mean $950 \mathrm{hPa}$ zonal wind speed anomalies from the LGM (shaded; contour interval is $0.5 \mathrm{~m} \mathrm{~s}^{-1}$ ) overlain with the sea surface current (reference vector is $10 \mathrm{~cm} \mathrm{~s}^{-1}$ ). (a) The LGM minus the H1 zonal wind speed anomaly overlain with the H1 sea surface current. (b) The LGM minus the YD zonal wind speed anomaly overlain with the YD sea surface current. (c) The LGM minus the onset of the Holocene zonal wind speed anomaly overlain with the onset of the Holocene sea surface current. Black boxes represent the IO and PO sectors.

\subsection{SO Upwelling}

Figure 1c,g and Figure 1d,h show the deglacial SO upwelling in the IO and the PO sectors, respectively. Spatially, the model simulated more vigorous upwelling in the IO than the PO sector at all timescales, which is consistent with present-day ocean circulation. The simulated upwelling core remained intact during all the time slices at both the ocean sectors, inferring that there was no significant spatial change in the deglacial Antarctic Circumpolar Current circulation. The model simulated the most vigorous upwelling during the LGM $(\approx 7 \mathrm{~Sv})$ in the IO sector, which was 5 to $7 \%$ stronger than in the H1, YD, and O_H (Figure $1 \mathrm{c}, \mathrm{g})$. The simulation showed that the upwelling core $\left(94^{\circ} \mathrm{E}\right.$ to $\left.109^{\circ} \mathrm{E}\right)$ weakened from the LGM to the YD and then reinvigorated in the O_H. In particular, in the PO sector, the $\mathrm{O} \_\mathrm{H}$ showed the greatest upwelling strength among the four millennial timescales (Figure 1d). Upwelling in the $\mathrm{O} \_\mathrm{H}(\approx 4 \mathrm{~Sv})$ was $4 \%$ stronger than in the LGM, indicating more vigorous upwelling at the end of deglaciation. Table 1 presents an overview of it.

Table 1. Descriptive analysis of the Southern Ocean (SO) wind stress and upwelling.

\begin{tabular}{ccccc}
\hline Time & $\begin{array}{c}\text { IO Sector: } \\
\text { Wind Stress } \\
\left(\mathbf{d y n e} \mathbf{c m}^{-\mathbf{2}}\right)\end{array}$ & $\begin{array}{c}\text { IO Sector: } \\
\text { Upwelling Volume } \\
\mathbf{( S v )}\end{array}$ & $\begin{array}{c}\text { PO Sector: } \\
\text { Wind Stress } \\
\mathbf{d y n e ~} \mathbf{~ c m}^{-2} \mathbf{)}\end{array}$ & $\begin{array}{c}\text { PO Sector: } \\
\text { Upwelling Volume } \\
\mathbf{( S v )}\end{array}$ \\
\hline LGM $^{1}$ & 2.58 & 6.93 & 1.58 & 3.92 \\
H1 & $-4.6 \%$ & $-5.3 \%$ & $-4.1 \%$ & $-6.9 \%$ \\
YD & $-5.9 \%$ & $-7.0 \%$ & $-2.1 \%$ & $-1.3 \%$ \\
O_H & $-6.2 \%$ & $-6.2 \%$ & $-6.1 \%$ & $\mathbf{+ 3 . 7 \%}$ \\
\hline
\end{tabular}

Note: All the values are as compared to the LGM. Units of the wind stress are in dyne per square centimeter $\left(\right.$ dyne $\mathrm{cm}^{-2}$ ). The upwelling volume is in Sverdrup (Sv). IO-Indian Ocean, PO-Pacific Ocean, LGM-Last Glacial Maximum, H1-Heinrich Stadial 1, YD-Younger Dryas, O_H—onset of the Holocene. ${ }^{1}$ Absolute values.

\subsection{Zonal Wind Stress}

The simulated wind stress during all the time slices in the IO sector was $\approx 36 \%$ stronger than the $\mathrm{PO}$ sector, in concordance with the $\approx 37 \%$ stronger upwelling volume. The simulated upwelling core overlapped spatially with the wind stress maxima. The SO upwelling in the IO sector had a strong correlation with wind stress maxima $\left(46^{\circ} \mathrm{S}\right)(r \approx 0.8$; 
$p<0.05$ ) (Figure 1c,g), whereas, in the PO sector, it had a Pearson correlation coefficient of about $0.2(p<0.05)$ (Figure $1 \mathrm{~d}, \mathrm{~h})$. In the IO sector, the area average wind stress during the LGM was 5 to $6 \%$ stronger than during the H1, YD, and O_H (Figure 4). In the PO sector, the area average wind stress in the LGM was $4 \%, 2 \%$, and $6 \%$ stronger than during the $\mathrm{H} 1, \mathrm{YD}$, and $\mathrm{O} \_\mathrm{H}$, respectively (Figure $4 \mathrm{~b}-\mathrm{d}$ ). Table 1 shows an overview of the simulated wind stresses.
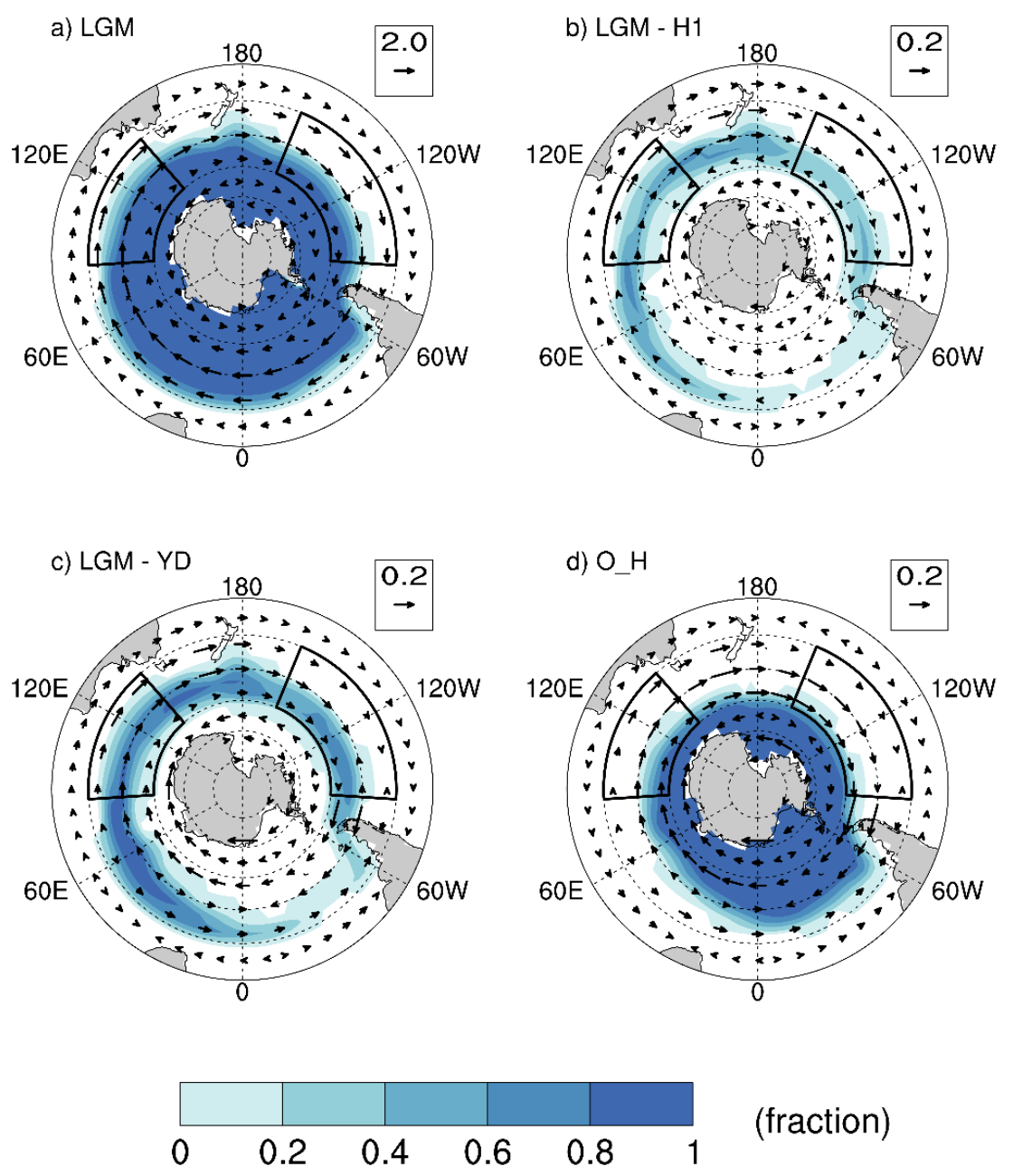

(fraction)

Figure 4. Annual average millennial mean sea ice fraction (shaded in color; units are given as a fraction (0 to 1)) overlain with the annual average millennial mean zonal wind stress vectors. (a) Sea ice fraction overlain with the wind stress in the LGM (reference vector is 2 dyne cm$^{-2}$ ). (b) The LGM minus the $\mathrm{H} 1$ sea ice fraction overlain with the LGM minus the $\mathrm{H} 1$ wind stress (reference vector is 0.2 dyne $\mathrm{cm}^{-2}$ ). (c) The LGM minus the YD sea ice fraction overlain with the LGM minus the YD wind stress (reference vector is 0.2 dyne $\mathrm{cm}^{-2}$ ). (d) The sea ice fraction at the onset of Holocene overlain with the LGM minus the onset of Holocene wind stress (reference vector is $0.2 \mathrm{dyne} \mathrm{cm}^{-2}$ ). Black boxes represent the IO and PO sectors. Sea surface devoid of sea ice is white.

\subsection{Antarctic Sea Ice}

The TraCE-21ka-modeled Antarctic sea ice coverage in the LGM was at a maximum in the IO sector (greater than a $70 \%$ sea ice fraction) in comparison to the PO sector $(\approx 30 \%$ sea ice fraction) (Figure 4a). Figure 4 illustrates the deglacial decrease in the Antarctic sea ice coverage, where its magnitude and range shrunk from the LGM to the O_H. In particular, during the $\mathrm{O} \_\mathrm{H}$, the PO sector was entirely devoid of sea ice. The model simulation suggests that the $\mathrm{SO}$ Antarctic sea ice coverage followed a similar trend to the deglacial decrease of the Southern Hemisphere surface westerlies and wind stress. 
Figure 5 illustrates the equatorward expansion of the denser surface water in the LGM. The sea ice boundary (defined as the ocean surface area's margin that is covered with more than $5 \%$ sea ice fraction) during the LGM roughly overlapped with surface density ranging from 27.5 to $27.7 \mathrm{~kg} \mathrm{~m}^{-3}$. Figure 6 highlights the close overlap between the transition from a negative to a positive buoyancy flux (solid blue contour line represents the boundary) and the edge of the ocean surface area covered by more than an $80 \%$ sea ice fraction. The simulation showed that in both of the ocean sectors, the latitudinal position of the transition zone of the buoyancy flux shifted poleward by $\approx 11^{\circ}$ from the LGM to the $\mathrm{O} \_\mathrm{H}$ (Table 2).
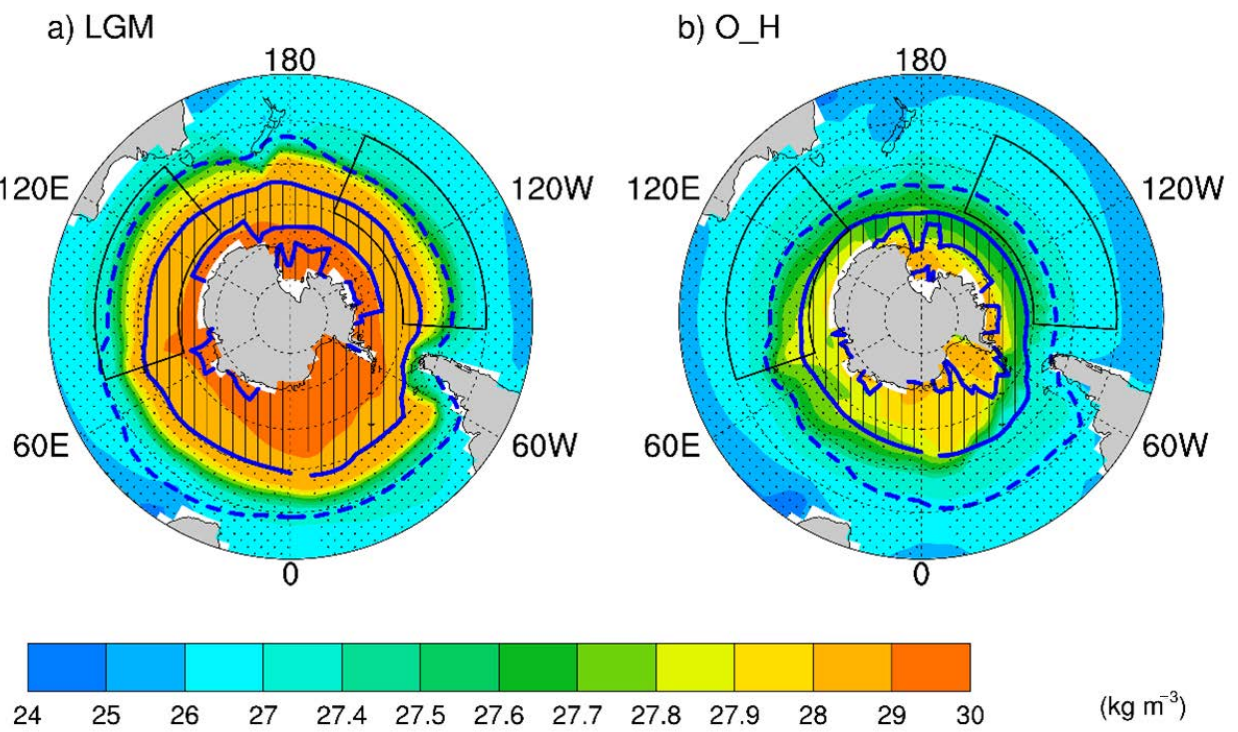

$\left(\mathrm{kg} \mathrm{m}^{-3}\right)$

Figure 5. Annual average millennial mean surface ocean density (shaded in color; units are in $\mathrm{kg} \mathrm{m}^{-3}$ (values reported after subtracting 1000; thus, a potential density of $27.6 \mathrm{~kg} \mathrm{~m}^{-3}$ is $1027.6 \mathrm{~kg} \mathrm{~m}^{-3}$ )). It is overlain with the annual average millennial mean sea ice boundary (margin of the ocean surface area covered with more than a 5\% sea ice fraction) (blue, dashed; contour lines) and the boundary between the negative and positive buoyancy fluxes (blue; solid; contour lines) during (a) the LGM and (b) the onset of the Holocene. A shaded pattern represents the region with denser surface ocean density (buoyancy loss, i.e., densification). The details about the estimation and change in buoyancy flux are in Section 4.2.
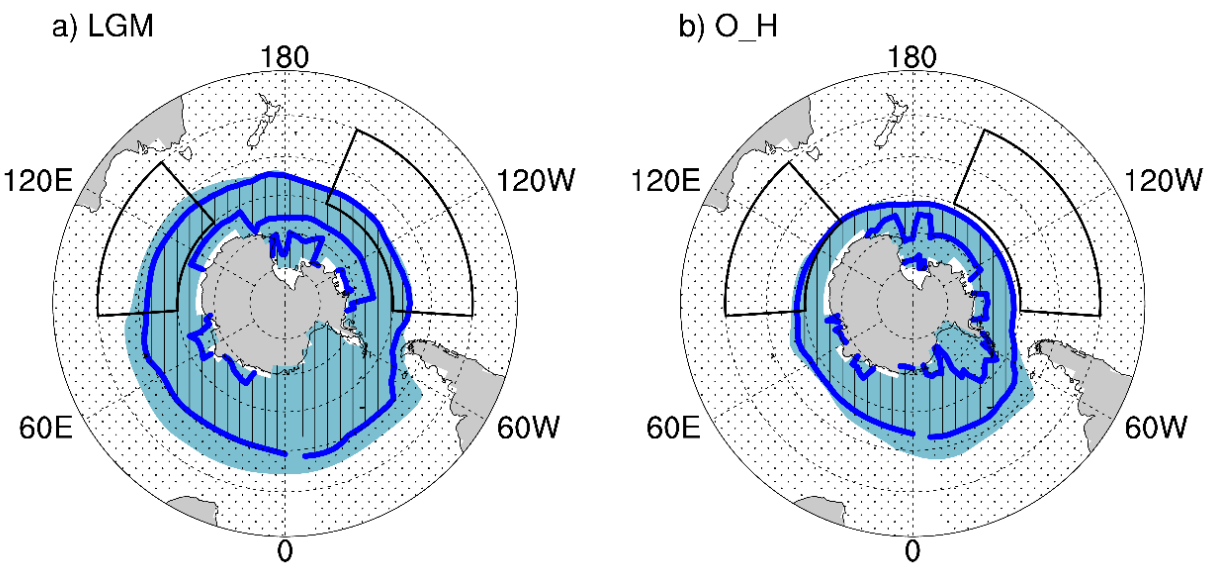

Figure 6. Annual average millennial mean coverage of more than an 80 percent fraction of ocean covered with sea ice (value $>0.8$; shaded in blue color; units are given as a fraction). It is overlain with the boundary between the negative and positive buoyancy fluxes (blue; solid; contour lines) during (a) the LGM and (b) the onset of the Holocene. A shaded pattern represents the area with denser surface ocean density (buoyancy loss). 
Table 2. Description of the latitudinal position of the sea ice and change in the buoyancy flux in the SO.

\begin{tabular}{cccc}
\hline Domain & Parameters & LGM & O_H \\
\hline IO sector & Sea ice fraction $(>80 \%)$ & $50^{\circ} \mathrm{S}$ & $61^{\circ} \mathrm{S}$ \\
IO sector & Zero buoyancy flux & $50^{\circ} \mathrm{S}$ & $61^{\circ} \mathrm{S}$ \\
PO sector & Sea ice fraction (>80\%) & $54^{\circ} \mathrm{S}$ & $65^{\circ} \mathrm{S}$ \\
PO sector & Zero buoyancy flux & $54^{\circ} \mathrm{S}$ & $65^{\circ} \mathrm{S}$ \\
\hline
\end{tabular}

Note: IO-Indian Ocean, PO-Pacific Ocean, LGM-Last Glacial Maximum, O_H—onset of the Holocene, zero buoyancy flux - transition between a negative and a positive buoyancy flux.

\section{Discussion}

The scarcity of paleo data and differing modeling results for the SO lead to disagreements regarding the mean condition of the LGM westerly flows. A recent study used TraCE-21ka simulations to show an equatorward migration of the mean position of Southern Hemisphere westerly winds in the LGM [45], in agreement with previous studies [3]. They also showed that TraCE-21ka simulates an abrupt poleward shift during the H1 and the YD, which is consistent with the modeling and paleo proxy evidence [9,58-63]. Moreover, in Section 2.2, we further found that the TraCE-21ka model performed well when simulating the changes in the near-surface winds and sea surface temperatures over the $\mathrm{SO}$ with present-day reanalysis. Therefore, we can agree that TraCE-21ka can successfully reproduce the Southern Hemisphere's natural variations during the last deglaciation.

\subsection{Role of Southern Hemisphere Westerlies}

TraCE-21ka simulated a pronounced zonal asymmetry during the LGM with an austral winter double jet at the SO's latitudes, which agrees with earlier studies [26,64]. This asymmetry in the Southern Hemisphere's westerly winds weakened during the H1 and the YD and was replaced by a single mid-latitude jet during the onset of the Holocene. Previous studies have mostly focused on the deglacial migration of the Southern Hemisphere's subtropical westerly jet and proxy moisture data as an analog to show the deglacial change of the zonal average Southern Hemisphere westerlies' circulation. However, it is essential to study the change in the strength of the surface Southern Hemisphere westerlies instead of the general Southern Hemisphere westerlies' circulation. Moreover, it is crucial to move beyond the average zonal perspective of the SO circulation.

Former modeling studies have shown that surface zonal wind stress changes represent the simulated change in the Southern Hemisphere westerlies' circulation [65]. Studies have revealed an increase or poleward shift of wind stress forcing results in enhanced winddriven SO upwelling $[3-5,7,9,61,62,66-70]$. The simulated deglacial Southern Hemisphere surface westerly winds varied in strength and spatial disposition, imposing varying wind stress over the $\mathrm{SO}$ and altering the wind-driven $\mathrm{SO}$ upwelling. Therefore, it is necessary to study the deglacial Southern Hemisphere surface westerly winds' change over the SO.

Our results show that the simulated deglacial surface Southern Hemisphere westerly winds and wind stress were the most vigorous during the LGM in both the IO and PO sectors (Figure 1g,h). Modeling and paleo proxy reconstruction studies of Southern Hemisphere westerlies agree with the TraCE-21ka simulated stronger westerlies during the LGM $[26,39,64,66,71-80]$. The TraCE-21ka simulation suggested a weakening trend of the $\mathrm{SO}$ westerlies through the last deglaciation.

Our result shows a strong correlation between the SO upwelling and wind stress maxima changing through the last deglaciation. In the IO sector, it decreased from very strong $(r \approx 0.8 ; p<0.05)$ (Figure 1g) during the LGM and early deglaciation (20 to $14.9 \mathrm{kyr} \mathrm{BP}$ ) to strong $(r \approx 0.7 ; p<0.05)$ (Figure $1 c)$ during the late deglaciation $(12.8$ to $9 \mathrm{kyr} \mathrm{BP})$. However, in the PO sector, it decreased from very strong $(r \approx 0.9 ; p<0.05)$ (Figure $1 \mathrm{~h})$ during the LGM and early deglaciation to strongly negative $(r \approx-0.7 ; p<0.05)$ (Figure $1 \mathrm{~d})$ during the late deglaciation. Thus, our analysis supports the idea that the Southern Hemisphere surface westerlies primarily drove the SO upwelling. The simulated Southern Hemisphere 
surface westerlies were the weakest during the onset of the Holocene, yet the SO upwelling increased in both sectors. Therefore, the wind-driven upwelling failed to explain the anomalous upwelling during the onset of Holocene, suggesting the role of other factors in determining the deglacial change in upwelling.

\subsection{Role of Sea Ice}

Production of sea ice affects the seawater's density and buoyancy, and accordingly, the SO stratification and circulation $[19,39,81]$. Sea ice formation results in salt flux injection (wintertime brine rejection) southward and freshwater flux (summertime melting) northward of the sea ice boundary. Less buoyant, denser ocean surface water forms via brine rejection and sinks around Antarctica under the sea ice. In this region, the heat flux is weak, and instead of temperature, salt controls the ocean water density [82]. The brine rejections and sea ice melting are the biggest contributors to surface freshwater forcing. It controls the change in buoyancy $\left(b=-g\left(\rho-\rho_{0}\right)\right)$, which is a deviation of ocean density $(\rho)$ from its reference value $\left(\rho_{o}=1027 \mathrm{~kg} \mathrm{~m}^{-3}\right)$ times gravitational acceleration $(g)$.

Buoyancy flux $\left(B_{0}\right)$ is the density flux across the air-sea interface and can be expressed as [83]:

$$
B_{o}=-g \alpha Q_{o} /\left(\rho c_{p}\right)+g \beta(E-P) S_{o},
$$

where $g$ is the gravitational acceleration, $\rho$ is ocean reference density, $c_{p}$ is the specific heat for seawater, $\alpha$ is the effective thermal expansion coefficient $\left(-\rho^{-1} \frac{\partial \rho}{\partial T}\right), T$ is the sea surface temperature, $Q_{o}$ is the net surface heat flux (incoming shortwave solar radiation + outgoing sensible heat flux + latent heat flux + longwave radiation), $\beta$ is the effective haline contraction coefficient $\left(\rho^{-1} \frac{\partial \rho}{\partial S}\right), S_{o}$ is the ocean surface salinity, $E$ is the rate of evaporation, and $P$ is the rate of precipitation. A positive buoyancy flux obtained from the definition, as shown in Equation (1) from [83] (represented by the shaded region in Figures 5 and 6) implies less buoyant surface water (buoyancy loss, i.e., densification), which is generated either by surface cooling, evaporation, or brine rejection that is associated with sea ice formation.

The $27.6 \mathrm{~kg} \mathrm{~m}^{-3}$ ocean density isopycnals coarsely mark the average transition between the lower and upper meridional overturning cells within the SO circulation [20]. Our analysis showed that the simulated deglacial sea ice boundary coarsely coincided with the surface ocean density ranging between 27.5 and $27.7 \mathrm{~kg} \mathrm{~m}^{-3}$, as highlighted in Figure 5. Therefore, we reasoned that the simulated deglacial sea ice boundary (margin of the ocean surface area covered with more than a 5\% sea ice fraction) approximately marked the boundary between the SO upper and lower meridional overturning cells'. Our investigation indicated that the edge of the ocean surface area covered with more than an $80 \%$ sea ice fraction thoroughly overlapped with the transition between the negative and positive buoyancy flux zones, as represented by a solid blue contour line in Figure 6. This implies that denser surface ocean water lay poleward to the ocean surface area covered with more than an $80 \%$ sea ice fraction, as illustrated in Figure 5.

However, the transition between the negative and positive buoyancy flux zones in the present-day climate coincided with the ocean surface area covered with a $70 \%$ sea ice fraction, as shown by [38]. This discrepancy in the simulated sea ice fraction could be due to a coarser resolution of the CSIM or the annual average data availability. Regardless, it is not significant whether the transition between the negative and positive buoyancy flux zones overlapped with $70 \%$ or $80 \%$ sea ice coverages. Our study highlighted that the transition between the negative and positive buoyancy flux zones coincided with the ocean surface covered with sea ice most of the year.

Past studies have shown that an increased salt flux during glacial times increased the Antarctic Bottom Water production and strengthened the lower overturning cell $[2,38,84]$. Idealized circulation model experiments [85] and dynamical scaling arguments [38] during the LGM have shown that a change in buoyancy forcing via an extended ocean sea ice coverage could expand the range of the Antarctic Bottom Water. We argue that the proportion of SO upwelling that upwells poleward to the ocean surface area covered with more 
than an $80 \%$ sea ice fraction would lose buoyancy by gaining surface water density, move poleward, and sink to form deep waters. Therefore, in an equatorward shift of annual ocean sea ice coverage, a larger fraction would upwell into denser surface waters, lose buoyancy, and strengthen the formation of deep waters.

In addition to an increase in deep water and Antarctic Bottom Water production, salt flux transport would also increase into the deep ocean. The passage of excess salt would make deep ocean water saltier. Moreover, during the glacial periods, extensive sea ice production in the SO would steepen the surface meridional (north-south) and the vertical (depth) density gradient [39]. The deep ocean is cold and the increase in salt flux during glacial times would stratify the ocean density structure and increase the vertical salinity gradient. The increase in a vertical salinity gradient would inhibit the vertical mixing of deep ocean waters. Furthermore, a freshwater flux from the summer sea ice melt would stratify the surface ocean $[12,78,86]$. Freshwater flux north of the permanent sea ice margin would likely move the upwelled water northward by increasing its buoyancy. The increase in the northward transport of more buoyant lighter surface waters would increase the meridional salinity gradient, thereby strengthening the upper meridional overturning cell [19].

Deglacial sea ice and surface density water variability would likely impact the energy exchange and the SO water mass production and circulation [42,43]. During an extended glacial sea ice coverage, the southward-flowing denser ocean water would circulate under sea ice. Therefore, sea ice would insulate the upper ocean from atmospheric forcing and act as a barrier to air-sea transfer by reducing the atmospheric exposure time of freshly upwelled waters [39-41].

\subsection{Response of SO Upwelling to the Wind and Sea Ice}

\subsubsection{Last Glacial Maximum}

The TraCE-21ka model simulation showed that the deglacial Southern Hemisphere Pacific basin underwent significant atmospheric and oceanographic changes. During the LGM, the model simulated the strongest deglacial near-surface zonal winds at the SO's latitudes. Recent studies support the TraCE-21ka simulation, where they agree with the stronger LGM Southern Hemisphere surface westerlies [39,80]. The TraCE-21ka model simulated the most vigorous deglacial SO upwelling during the LGM, and a study by [87] supports the simulation. Our analysis indicated that surface westerlies primarily drove the SO upwelling.

During the LGM, global cooling due to lower atmospheric greenhouse gas concentrations (Figure 1e) resulted in the simulated equatorward expansion of the glacial sea ice coverage area to $\approx 45^{\circ} \mathrm{S}$ in the IO and PO sectors (Figure $4 \mathrm{a}$ ). The model-simulated equatorward extension of the LGM sea ice agrees with previous studies [38,79,80,86,88-90]. Our results highlighted that during the LGM, the ocean surface area covered with more than an $80 \%$ sea ice fraction overlapped with a transition between the negative and positive buoyancy fluxes (Figure 6 ). It was positioned $\approx 11^{\circ}$ equatorward compared to during the O_H (Table 2). The simulated equatorward extension of denser ocean surface water during the LGM agrees with past studies [12,38]. The simulation showed that the LGM deep ocean was extensively stratified (Figure 7a) and colder and saltier (Figure $7 \mathrm{~b}$ ) than during the O_H and agreed with previous studies [12,28,91-93].

The simulation showed that the extensive coverage of sea ice during the LGM led to a massive influx of salt into the ocean compared to the O_H, as shown in Figure 8a. Our results showed that the vertical salinity (illustrated in Figure 7a) and density gradient of the LGM deep ocean water was seven and two times stronger than during the O_H, respectively, as shown in Table 3. This extensive stratification of the LGM deep ocean waters would subsequently lead to low vertical diffusion and less mixing of the LGM waters [92,94]. Regarding the LGM, Figure 8c highlights the intensive freshwater flux into lighter surface waters at the sea ice boundary. Our analysis showed that the LGM meridional salinity gradient was stronger by a factor of nine relative to during the O_H 
(Table 3). This increase in simulated freshwater flux and meridional salinity gradient would strengthen the glacial upper meridional overturning circulation, which is consistent with [19]. The simulation of the Global Meridional Overturning Circulation ( 0.5 to $4.5 \mathrm{~km}$ depth) during the LGM (Figure 9a) showed an extended lower meridional overturning cell (blue), an upper meridional overturning cell (red), and a shallower Deacon cell ( $\approx 45^{\circ} \mathrm{S}$ to $60^{\circ} \mathrm{S}$; red). The LGM lower meridional overturning cell comprising the Antarctic Bottom Water and its derivatives expanded above the average topographic features in the $\mathrm{SO}$ to depths of about $1600 \mathrm{~m}$ (Figure 9b). Previous studies have also reported expanded lower meridional overturning circulation during the LGM $[38,90,95,96]$. Our analysis showed that the strength of the maximum lower meridional overturning transport during the LGM was about 1.3 times stronger than during the $\mathrm{O} \_\mathrm{H}$ (Table 3).
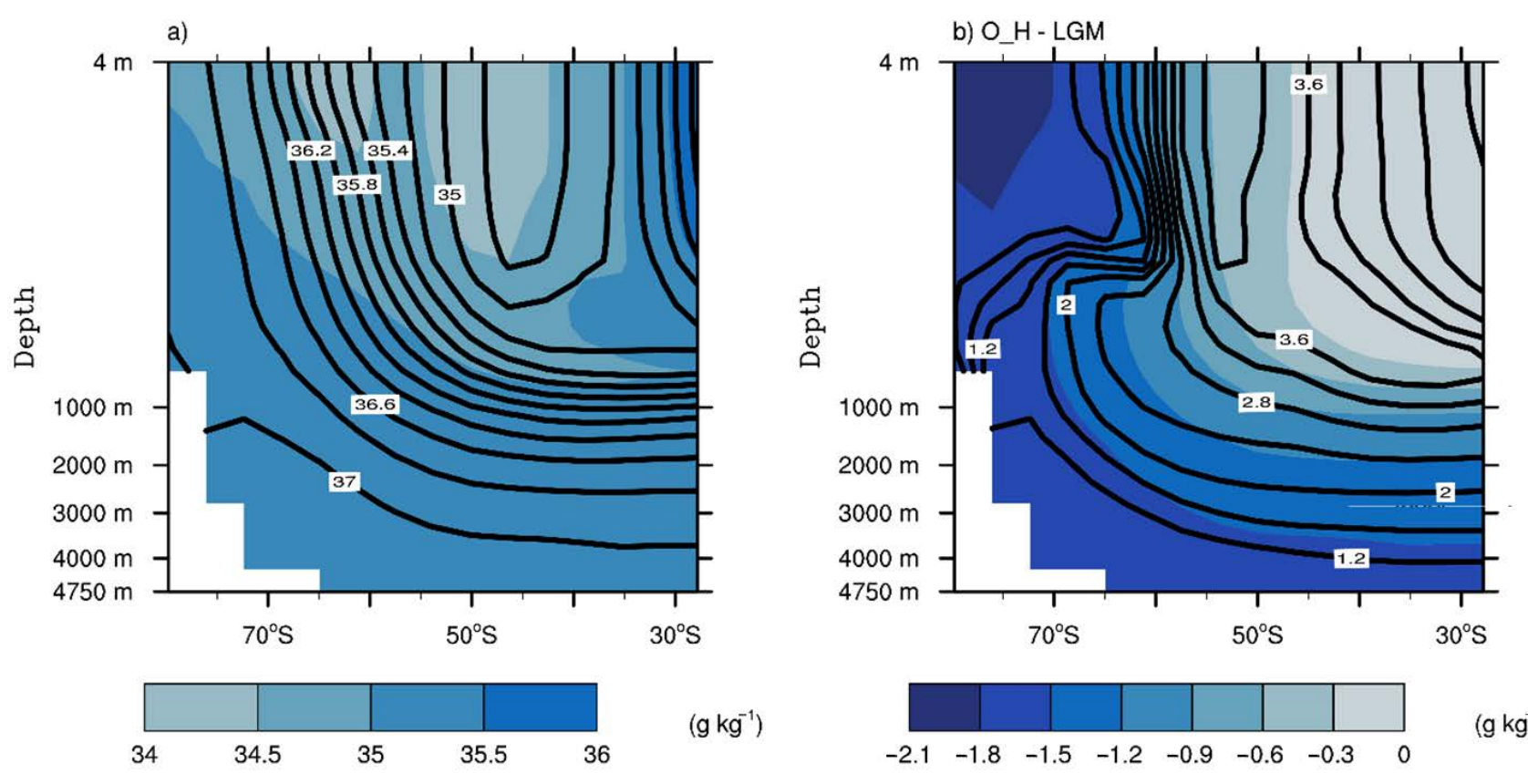

Figure 7. (a) The annual average millennial mean salinity during the onset of the Holocene (shaded; contour interval is $0.5 \mathrm{~g} \mathrm{~kg}^{-1}$ ). It is overlain with the yearly average millennial mean salinity during the LGM (contours; solid; contour interval is $\left.0.2 \mathrm{~g} \mathrm{~kg}^{-1}\right)$ in the $\mathrm{PO}$ basin $\left(170^{\circ} \mathrm{W}\right.$ to $\left.86^{\circ} \mathrm{W}\right)$. (b) The annual average millennial mean salinity (shaded; contour interval is $0.3 \mathrm{~g} \mathrm{~kg}^{-1}$ ) overlain with the ocean temperature (contours; solid; contour interval is $0.4{ }^{\circ} \mathrm{C}$ ) during the onset of the Holocene compared to the LGM in the PO basin.

Table 3. Description of the parameters that were influenced by sea ice.

\begin{tabular}{cccc}
\hline Parameters & Domain & LGM & O_H \\
\hline MSG & IO sector & 0.9 & 0.11 \\
MSG & PO sector & 0.69 & 0.07 \\
VSG & Pacific basin & -0.26 & -0.04 \\
VDG & Pacific basin & -0.24 & -0.12 \\
Maximum lower MOC transport & Global & 20 & 16 \\
\hline
\end{tabular}

Note: MSG—meridional salinity gradient, VSG—vertical salinity gradient, VDG—vertical density gradient, IO-Indian Ocean, PO—Pacific Ocean, LGM-Last Glacial Maximum, O_H—onset of the Holocene, MOCMeridional Overturning Circulation. The meridional salinity gradient is the difference between the salinity within $65^{\circ} \mathrm{S}$ to $54^{\circ} \mathrm{S}$ and $54^{\circ} \mathrm{S}$ to $43^{\circ} \mathrm{S}$ above a 70-meter ocean depth. The vertical gradients are the differences between 1.8 to $2.7 \mathrm{~km}$ and 2.7 to $4.7 \mathrm{~km}$ ocean depths within $50^{\circ} \mathrm{S}$ to $30^{\circ} \mathrm{S}$. The salinity gradient unit is in grams per kilogram $\left(\mathrm{g} \mathrm{kg}^{-1}\right)$, and the density gradient is in kilograms per cubic meter $\left(\mathrm{kg} \mathrm{m}^{-3}\right)$. The maximum lower meridional overturning transport is the model maximum meridional transport below $2 \mathrm{~km}$ of ocean depth; its unit is in Sverdrups (Sv). 


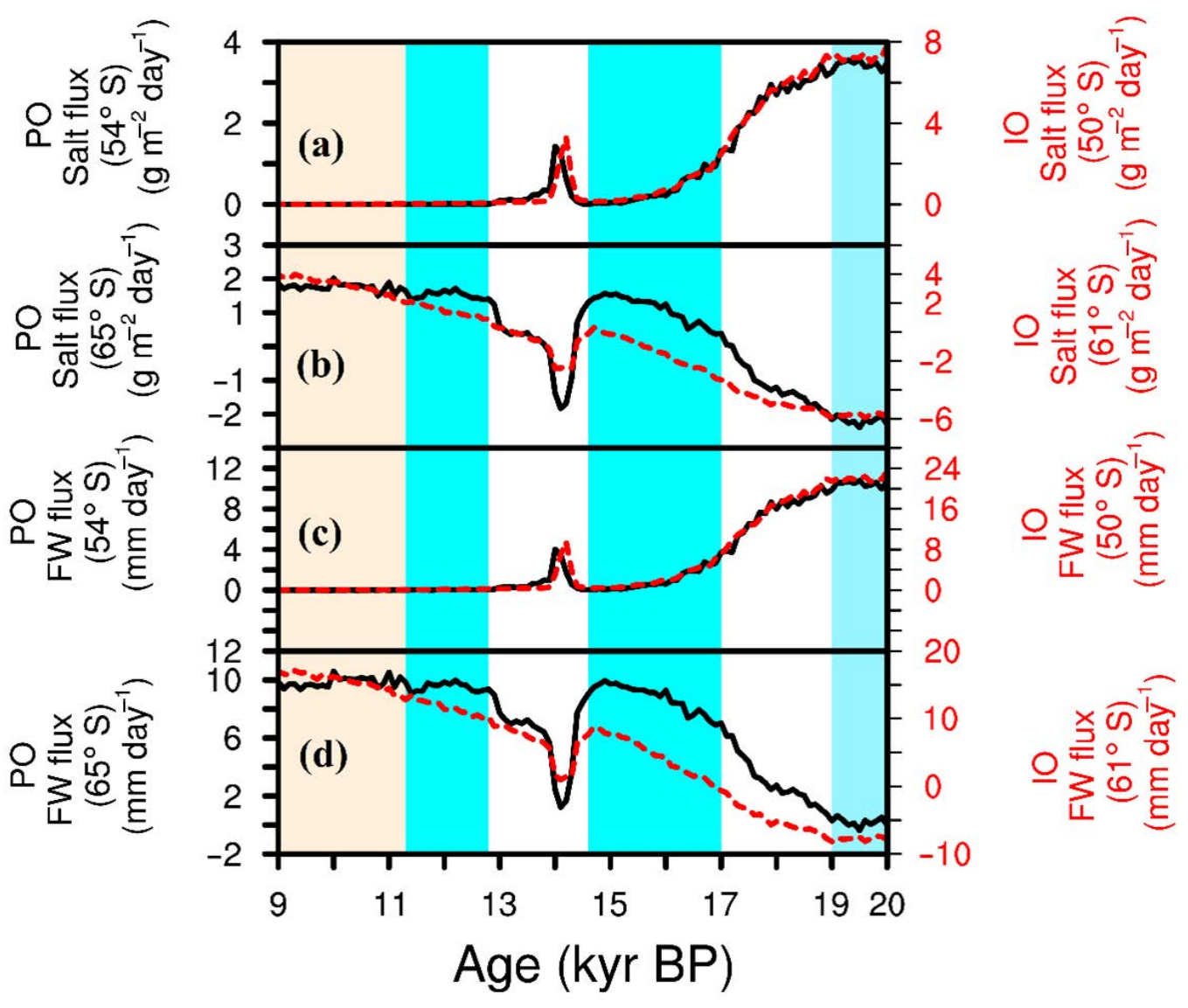

Figure 8. The annual average millennial mean salt flux at the boundary between the negative and positive buoyancy fluxes in the IO (red, dashed; units are in grams per square meter per day $\left(\mathrm{g} \mathrm{m}^{-2} \mathrm{day}^{-1}\right)$ ) and PO (black; solid; units are in grams per square meter per day $\left(\mathrm{g} \mathrm{m}^{-2}\right.$ day $\left.^{-1}\right)$ ) sectors during (a) the LGM and (b) the onset of the Holocene periods. The average annual millennial mean freshwater flux at the transition between the negative and positive buoyancy fluxes in the IO (red, dashed; units are in millimeters per day $\left(\mathrm{mm}\right.$ day $\left.{ }^{-1}\right)$ ) and PO (black; solid; units are in millimeters per day $\left(\mathrm{mm} \mathrm{day}^{-1}\right)$ ) sectors during (c) the LGM and (d) the onset of the Holocene periods.

The expansion of the LGM sea ice resulted in the extension and shoaling of the lower meridional overturning cell, as shown in Figure 9b. The deep ocean waters were saltier and extensively stratified. This led to weaker vertical diffusion and a lack of turbulent mixing of carbon-rich waters from the lower meridional overturning cell with the overlying carbondeficient waters [38]. The poorly mixed water would reach the ocean surface under the extended coverage of sea ice, which would likely restrict the outgassing of $\mathrm{CO}_{2}[42,43,97]$. Furthermore, the TraCE-21ka-simulated colder and expanded LGM deep ocean water would increase the deep ocean carbon storage [96].

\subsubsection{Deglaciation: $\mathrm{H} 1$ and $\mathrm{YD}$}

The wind stress-upwelling analogy was retained well in the TraCE-21ka-simulated H1 and YD climatologies. During the H1 and the YD, the model simulated a southward shift in the Intertropical Convergence Zone position (Figure S3) and more vigorous wind stress forcing in the latitudes of the SO in comparison to the $\mathrm{O} \_\mathrm{H}$. The simulated increase in the SO upwelling in response to the strengthened surface Southern Hemisphere westerlies during the $\mathrm{H} 1$ and the YD was consistent with the upwelling records $[9,98]$.

The deglacial climate experienced Northern Hemisphere meltwater discharge during the $\mathrm{H} 1$ and YD (Figure 1b,f) events. The simulation showed that the northern Atlantic meltwater discharge weakened the Atlantic Meridional Ocean Circulation and reduced the supply of North Atlantic origin waters into the SO's latitudes. The meltwater forcings 
led to the associated Southern Hemisphere Pacific bipolar seesaw [99], and deep ocean warming resulted in the Antarctic sea ice's deglacial retreat. During the H1 and the YD, the sea ice retreated poleward from its equatorward position during the LGM. The SO deep waters were fresher and less stratified than the LGM waters. The simulation showed that the lower overturning cell during the $\mathrm{H} 1$ and the YD was less expanded than the LGM. Consequently, this may have resulted in more turbulent mixing of carbon-rich water from the lower meridional overturning cell with the overlying waters $[12,38]$.
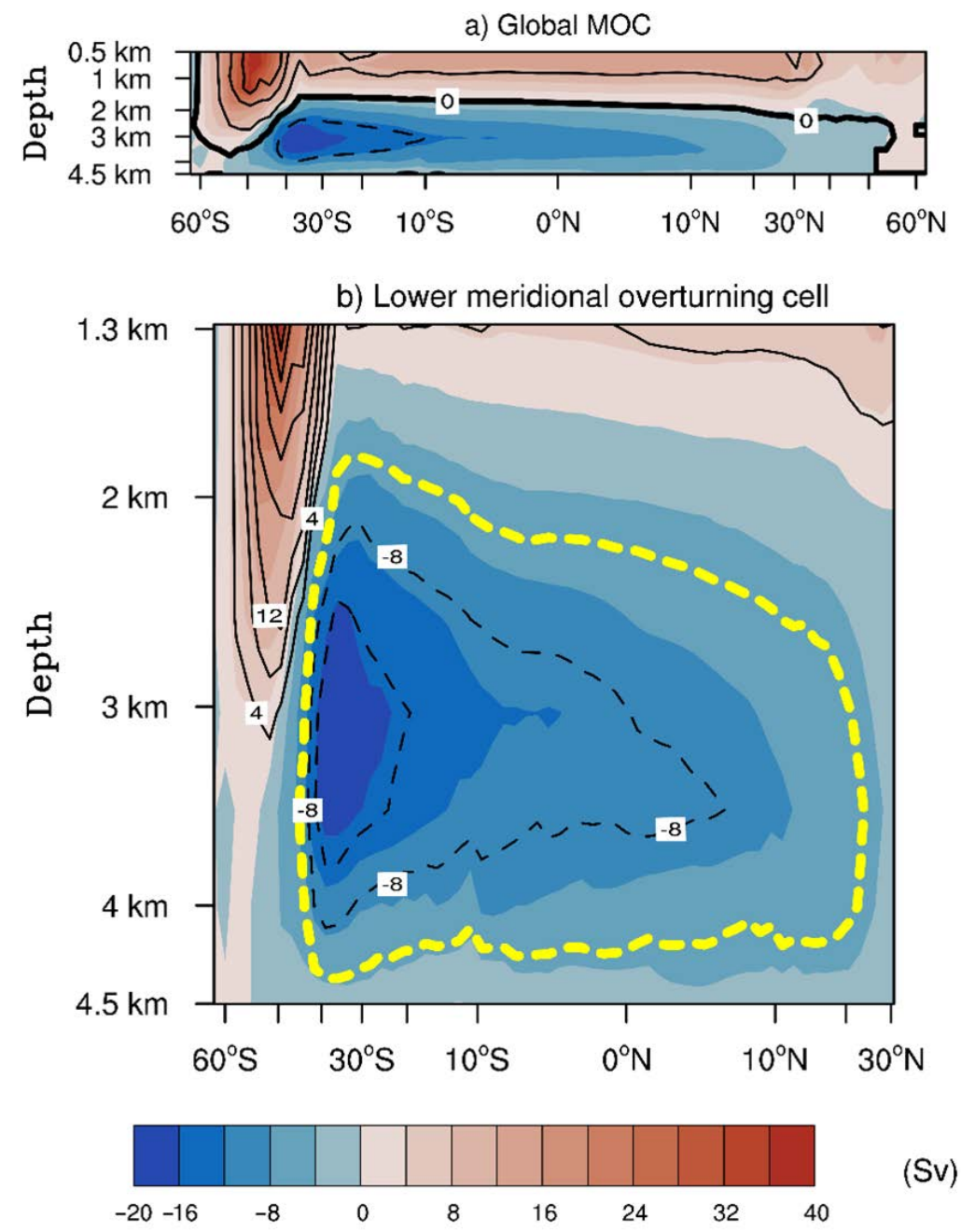

Figure 9. The Global MOC stream function during the LGM (shaded contour interval) overlain with the MOC stream function during the onset of the Holocene (line contour interval). (a) Section of the Global MOC ( 0.5 to $4.5 \mathrm{~km}$ depth) showing an upper meridional overturning cell (red), a shallower Deacon cell ( $\approx 45^{\circ} \mathrm{S}$ to $60^{\circ} \mathrm{S}$; red), and a lower meridional overturning cell (blue) (shaded contour interval is $4 \mathrm{~Sv}$ and the line contour interval is $10 \mathrm{~Sv}$ ). (b) Detailed overview of the lower section of the Global MOC (1.3 to $4.5 \mathrm{~km}$ depth) (shaded and the line contour interval is $4 \mathrm{~Sv}$ ) from Figure 9a. It highlights the lower meridional overturning cell (blue). The bold, dashed, and yellow color contour line shows the lower meridional overturning cell's extent during the onset of the Holocene.

Enhanced upwelling during the $\mathrm{H} 1$ and the YD would likely bring more carbonrich water to the ocean's surface. The reduction in the sea ice coverage would enhance the outgassing of $\mathrm{CO}_{2}[42,43,97]$. Furthermore, the ocean water during the $\mathrm{H} 1$ and the YD was warmer than the LGM and decreased the solubility of $\mathrm{CO}_{2}$. The TraCE-21kamodeled upwelling records during the $\mathrm{H} 1$ and the $\mathrm{YD}$ were consistent with the increase in atmospheric $\mathrm{CO}_{2}$ concentrations from ice core records [11] (Figure 1a,e). 


\subsubsection{Deglaciation: Onset of the Holocene}

The wind stress-upwelling analogy did not fit with the inconsistent increase in upwelling during the O_H, especially in the PO sector (Figure 1d). Meltwater fluxes from changing continental ice sheets and increases in insolation and greenhouse gasses resulted in Southern Hemisphere deglacial deep ocean warming (Figure 7b) and Antarctic sea ice's deglacial retreat (Figure 4). The simulated IO sector was partially devoid of sea ice and the PO sector was entirely free of sea ice (Figure $4 \mathrm{~d}$ ) during the $\mathrm{O} \_\mathrm{H}$.

Our results highlighted that the absence of sea ice made the SO deep waters fresher (Figure $7 \mathrm{~b}$ ) and less stratified (Figure 7a) compared to the LGM. The lower meridional overturning cell's upper margin during the O_H moved deeper to about $1900 \mathrm{~m}$ than the shallower LGM lower meridional overturning cell (Figure 9b). The simulation showed that the strength of the upper meridional overturning cell (Atlantic Meridional Ocean Circulation) was about two times stronger during the O_H compared with during the H1 and the YD. This would likely bring low carbon-rich waters into the upper meridional overturning cell. Additionally, the magnitude of the simulated freshwater flux increased by 3 times in the IO and 52 times in the PO sectors compared to the LGM, as shown in Figure $8 \mathrm{~d}$. The increased freshwater flux at the O_H sea ice boundary latitudes would strengthen the upper meridional overturning cell's circulation. Therefore, our analysis highlighted that the increase in freshwater flux during the O_H explains the anomalous SO upwelling.

Modern satellite and modeling studies have emphasized the importance of the seaice-induced freshwater flux. Recent studies have indicated that the SO freshwater flux alters the salinity, vertical and meridional density gradients, and thermohaline circulation of the modern ocean [100]. Moreover, an estimated annual northward sea ice freshwater flux from Antarctica [100] shows comparable sea ice freshwater transport to the O_H. Our study suggested that it is vital to understand the implication of sea ice induced freshwater transport changes to understand the future $\mathrm{SO}$ climate changes.

Moreover, the absence of sea ice would increase energy transfer efficiency from the atmosphere to the ocean $[42,43]$ compared to the LGM, suggesting an increase in SO upwelling. The dynamical changes in the carbon content of SO upwelling water are beyond the scope of this study. However, it is crucial to understand that the deglacial retreat of Antarctic sea ice changed the SO circulation and the vertical and turbulent mixing of SO deep waters, thereby changing the upwelling waters' carbon content.

\section{Conclusions}

This article investigated the deglacial Southern Ocean upwelling's evolution on a subbasin scale using a fully coupled global climate TraCE-21ka model. The main conclusions from this work are as follows:

(1). The model simulated the deglacial evolution of the Southern Hemisphere surface westerlies, and the Antarctic sea ice, which agreed with proxy records. It established TraCE-21ka's consistency and applicability in simulating the physical mechanisms that determine the Southern Ocean upwelling.

(2). The Southern Hemisphere surface westerly winds were strong during the Last Glacial Maximum, Heinrich Stadial 1, and Younger Dryas compared to during the onset of the Holocene, with the Last Glacial Maximum's westerly winds being the strongest.

(3). Intense surface westerly winds and the subsequent wind stress forcing over the Southern Ocean resulted in more vigorous upwelling during the Last Glacial Maximum, Heinrich Stadial 1, and Younger Dryas. Our investigation indicated that the strength of the wind stresses primarily governs the variability in the Southern Ocean upwelling around Antarctica.

(4). The strong simulated upwelling in both the ocean sectors during the onset of the Holocene cannot be explained by weaker wind stress forcing. This study suggested that the sea ice modulated the buoyancy forcing via an enhanced freshwater flux, and 
together with the zonal wind stress forcing, describes the strong upwelling during the onset of Holocene.

(5). The Antarctic sea ice expansion during the Last Glacial Maximum was dynamically linked to an increase in deep ocean stratification. Moreover, it resulted in the extension, shoaling, and increase in transport of the lower meridional overturning circulation (Antarctic Bottom Water and its derivatives) during the Last Glacial Maximum. Additionally, the Antarctic sea ice affected the surface buoyancy flux via freshwater and salt fluxes. It also regulated the Southern Ocean circulation by marking the division between the upper (Atlantic Meridional Ocean Circulation) and lower meridional overturning ocean circulation.

(6). This study highlighted that the evolution of the Southern Hemisphere westerly winds and sea ice history is essential in understanding the ocean-atmosphere coupling at high latitudes and its role in changing the deglacial Southern Ocean upwelling. The TraCE-21ka simulation demonstrated that the Southern Ocean atmosphere, ocean, and cryosphere were dynamically interlinked. The changes in the Southern Hemisphere westerlies, Southern Ocean upwelling, and Antarctic sea ice change must have cooccurred through the last deglaciation during the late Pleistocene. This relationship is vital to include in future climate modeling studies to understand the Southern Ocean upwelling variations. Our results may help to understand the natural global warming process and its consequences for the Southern Ocean dynamics.

Supplementary Materials: The following are available online at https:/ /www.mdpi.com/2071-105 0/13/1/353/s1, Figure S1: TraCE-21ka model simulation comparison with present-day near-surface $950 \mathrm{hPa}$ zonal wind climatology, Figure S2: TraCE-21ka model simulation comparison with presentday sea surface temperature climatology, Figure S3: TraCE-21ka model simulated global Intertropical Convergence Zone position.

Author Contributions: Conceptualization: G.M. and S.-Y.L.; methodology: G.M. and S.-Y.L.; validation: G.M.; formal analysis: G.M.; investigation: G.M.; resources: S.-Y.L.; writing—original draft preparation: G.M.; writing-review and editing: G.M., S.-Y.L. and J.-Y.Y.; visualization: G.M.; supervision: S.-Y.L. and J.-Y.Y.; project administration: S.-Y.L.; funding acquisition: S.-Y.L. and G.M. All authors have read and agreed to the published version of the manuscript.

Funding: The Ministry of Science and Technology of Taiwan (MOST) provided grants \#107-2611-M001-006-, \#106-2611-M-001-001-, and \#107-2119-M-002-051- to Gagan Mandal and Shih-Yu Lee. Furthermore, a Taiwan International Graduate Program (TIGP) scholarship was awarded by Academia Sinica to Gagan Mandal.

Data Availability Statement: The model data are available at the public domain (https://www. earthsystemgrid.org/project/trace.html).

Acknowledgments: We are indebted to the team behind the TraCE-21ka experiments for generating and sharing the model output, which is publicly available via the National Center for Atmospheric Research Climate Data Gateway. We want to thank the anonymous reviewers for their suggestions, which significantly improved the manuscript. We also thank Gary Strand, the software engineer at NCAR, for helping us with the data.

Conflicts of Interest: The authors declare no conflict of interest.

\section{References}

1. Karl, T.R.; Trenberth, K.E. Modern global climate change. Science 2003, 302, 1719-1723. [CrossRef] [PubMed]

2. Watson, A.J.; Vallis, G.K.; Nikurashin, M. Southern Ocean buoyancy forcing of ocean ventilation and glacial atmospheric $\mathrm{CO}_{2}$. Nat. Geosci. 2015, 8, 861-864. [CrossRef]

3. Toggweiler, J.R.; Russell, J.L.; Carson, S.R. Midlatitude westerlies, atmospheric $\mathrm{CO}_{2}$, and climate change during the ice ages. Paleoceanography 2006, 21, PA2005. [CrossRef]

4. Lourantou, A.; Chappellaz, J.; Barnola, J.M.; Masson-Delmotte, V.; Raynaud, D. Changes in atmospheric $\mathrm{CO}_{2}$ and its carbon isotopic ratio during the penultimate deglaciation. Quat. Sci. Rev. 2010, 29, 1983-1992. [CrossRef]

5. Rose, K.A.; Sikes, E.L.; Guilderson, T.P.; Shane, P.; Hill, T.M.; Zahn, R.; Spero, H.J. Upper-ocean-to-atmosphere radiocarbon offsets imply fast deglacial carbon dioxide release. Nature 2010, 466, 1093-1097. [CrossRef] 
6. Lauderdale, J.M.; Garabato, A.C.N.; Oliver, K.I.C.; Follows, M.J.; Williams, R.G. Wind-driven changes in Southern Ocean residual circulation, ocean carbon reservoirs and atmospheric $\mathrm{CO}_{2}$. Clim. Dyn. 2013, 41, 2145-2164. [CrossRef]

7. Lauderdale, J.M.; Williams, R.G.; Munday, D.R.; Marshall, D.P. The impact of Southern Ocean residual upwelling on atmospheric $\mathrm{CO}_{2}$ on centennial and millennial timescales. Clim. Dyn. 2017, 48, 1611-1631. [CrossRef]

8. Spero, H.J.; Lea, D.W. The cause of carbon isotope minimum events on glacial terminations. Science 2002, 296, 522-525. [CrossRef]

9. Anderson, R.F.; Ali, S.; Bradtmiller, L.I.; Nielsen, S.H.H.; Fleisher, M.Q.; Anderson, B.E.; Burckle, L.H. Wind-Driven Upwelling in the Southern Ocean and the Deglacial Rise in Atmospheric $\mathrm{CO}_{2}$. Science 2009, 323, 1443-1448. [CrossRef]

10. Ahn, J.; Brook, E.J. Atmospheric $\mathrm{CO}_{2}$ and climate on millennial time scales during the last glacial period. Science 2008, $322,83-85$. [CrossRef]

11. Monnin, E.; Indermuhle, A.; Dallenbach, A.; Fluckiger, J.; Stauffer, B.; Stocker, T.F.; Raynaud, D.; Barnola, J.M. Atmospheric CO 2 concentrations over the last glacial termination. Science 2001, 291, 112-114. [CrossRef] [PubMed]

12. Skinner, L.C.; Fallon, S.; Waelbroeck, C.; Michel, E.; Barker, S. Ventilation of the deep Southern Ocean and deglacial $\mathrm{CO}_{2}$ rise. Science 2010, 328, 1147-1151. [CrossRef]

13. Joos, F.; Spahni, R. Rates of change in natural and anthropogenic radiative forcing over the past 20,000 years. Proc. Natl. Acad. Sci. USA 2008, 105, 1425-1430. [CrossRef] [PubMed]

14. Bauska, T.K.; Baggenstos, D.; Brook, E.J.; Mix, A.C.; Marcott, S.A.; Petrenko, V.V.; Schaefer, H.; Severinghaus, J.P.; Lee, J.E. Carbon isotopes characterize rapid changes in atmospheric carbon dioxide during the last deglaciation. Proc. Natl. Acad. Sci. USA 2016, 113, 3465-3470. [CrossRef] [PubMed]

15. Menviel, L.; Spence, P.; Yu, J.; Chamberlain, M.A.; Matear, R.J.; Meissner, K.J.; England, M.H. Southern Hemisphere westerlies as a driver of the early deglacial atmospheric $\mathrm{CO}_{2}$ rise. Nat. Commun. 2018, 9, 2503. [CrossRef] [PubMed]

16. Kuhlbrodt, T.; Griesel, A.; Montoya, M.; Levermann, A.; Hofmann, M.; Rahmstorf, S. On the driving processes of the Atlantic meridional overturning circulation. Rev. Geophys. 2007, 45, RG2001. [CrossRef]

17. Imbrie, J.; Boyle, E.A.; Clemens, S.C.; Duffy, A.; Howard, W.R.; Kukla, G.; Kutzbach, J.; Martinson, D.G.; McIntyre, A.; Mix, A.C.; et al. On the Structure and Origin of Major Glaciation Cycles 1. Linear Responses to Milankovitch Forcing. Paleoceanography 1992, 7, 701-738. [CrossRef]

18. Marshall, J.; Speer, K. Closure of the meridional overturning circulation through Southern Ocean upwelling. Nat. Geosci. 2012, 5, 171-180. [CrossRef]

19. Abernathey, R.P.; Cerovecki, I.; Holland, P.R.; Newsom, E.; Mazloff, M.; Talley, L.D. Water-mass transformation by sea ice in the upper branch of the Southern Ocean overturning. Nat. Geosci. 2016, 9, 596-601. [CrossRef]

20. Lumpkin, R.; Speer, K. Global Ocean Meridional Overturning. J. Phys. Oceanogr. 2007, 37, 2550-2562. [CrossRef]

21. Allison, L.C.; Johnson, H.L.; Marshall, D.P.; Munday, D.R. Where do winds drive the Antarctic Circumpolar Current? Geophys. Res. Lett. 2010, 37, L12605. [CrossRef]

22. Broecker, W.S. Glacial to interglacial changes in ocean chemistry. Prog. Oceanogr. 1982, 11, 151-197. [CrossRef]

23. Hodell, D.A.; Venz, K.A.; Charles, C.D.; Ninnemann, U.S. Pleistocene vertical carbon isotope and carbonate gradients in the South Atlantic sector of the Southern Ocean. Geochem. Geophys. Geosystems. 2003, 4, 1-19. [CrossRef]

24. Menviel, L.; Timmermann, A.; Mouchet, A.; Timm, O. Climate and marine carbon cycle response to changes in the strength of the Southern Hemispheric westerlies. Paleoceanography 2008, 23. [CrossRef]

25. d'Orgeville, M.; Sijp, W.P.; England, M.H.; Meissner, K.J. On the control of glacial-interglacial atmospheric $\mathrm{CO}_{2}$ variations by the Southern Hemisphere westerlies. Geophys. Res. Lett. 2010, 37, L21703. [CrossRef]

26. Shulmeister, J.; Goodwin, I.; Renwick, J.; Harle, K.; Armand, L.; McGlone, M.S.; Cook, E.; Dodson, J.; Hesse, P.P.; Mayewski, P.; et al. The Southern Hemisphere westerlies in the Australasian sector over the last glacial cycle: A synthesis. Quatern. Int. 2004, 118, 23-53. [CrossRef]

27. Tschumi, T.; Joos, F.; Parekh, P. How important are Southern Hemisphere wind changes for low glacial carbon dioxide? A model study. Paleoceanography 2008, 23, PA4208. [CrossRef]

28. Martínez Fontaine, C.; De Pol-Holz, R.; Michel, E.; Siani, G.; Reyes-Macaya, D.; Martínez-Méndez, G.; DeVries, T.; Stott, L.; Southon, J.; Mohtadi, M.; et al. Ventilation of the Deep Ocean Carbon Reservoir During the Last Deglaciation: Results From the Southeast Pacific. Paleoceanogr. Paleoclimatol. 2019. [CrossRef]

29. Straub, D.N. On the Transport and Angular Momentum Balance of Channel Models of the Antarctic Circumpolar Current. J. Phys. Oceanogr. 1993, 23, 776-782. [CrossRef]

30. Hallberg, R.; Gnanadesikan, A. An Exploration of the Role of Transient Eddies in Determining the Transport of a Zonally Reentrant Current. J. Phys. Oceanogr. 2001, 31, 3312-3330. [CrossRef]

31. Hallberg, R.; Gnanadesikan, A. The Role of Eddies in Determining the Structure and Response of the Wind-Driven Southern Hemisphere Overturning: Results from the Modeling Eddies in the Southern Ocean (MESO) Project. J. Phys. Oceanogr. 2006, 36, 2232-2252. [CrossRef]

32. Meredith, M.P.; Hogg, A.M. Circumpolar response of Southern Ocean eddy activity to a change in the Southern Annular Mode. Geophys. Res. Lett. 2006, 33, L16608. [CrossRef]

33. Abernathey, R.; Marshall, J.; Ferreira, D. The Dependence of Southern Ocean Meridional Overturning on Wind Stress. J. Phys. Oceanogr. 2011, 41, 2261-2278. [CrossRef]

34. Wolfe, C.L.; Cessi, P. The Adiabatic Pole-to-Pole Overturning Circulation. J. Phys. Oceanogr. 2011, 41, 1795-1810. [CrossRef] 
35. Meredith, M.P.; Naveira Garabato, A.C.; Hogg, A.M.; Farneti, R. Sensitivity of the Overturning Circulation in the Southern Ocean to Decadal Changes in Wind Forcing. J. Clim. 2012, 25, 99-110. [CrossRef]

36. Morrison, A.K.; McC. Hogg, A. On the Relationship between Southern Ocean Overturning and ACC Transport. J. Phys. Oceanogr. 2013, 43, 140-148. [CrossRef]

37. Munday, D.R.; Johnson, H.L.; Marshall, D.P. Eddy Saturation of Equilibrated Circumpolar Currents. J. Phys. Oceanogr. 2013, 43, 507-532. [CrossRef]

38. Ferrari, R.; Jansen, M.F.; Adkins, J.F.; Burke, A.; Stewart, A.L.; Thompson, A.F. Antarctic sea ice control on ocean circulation in present and glacial climates. Proc. Natl. Acad. Sci. USA 2014, 111, 8753-8758. [CrossRef]

39. Stein, K.; Timmermann, A.; Kwon, E.Y.; Friedrich, T. Timing and magnitude of Southern Ocean sea ice/carbon cycle feedbacks. Proc. Natl. Acad. Sci. USA 2020, 117, 4498-4504. [CrossRef]

40. Miller, G.H.; Wolfe, A.P.; Steig, E.J.; Sauer, P.E.; Kaplan, M.R.; Briner, J.P. The Goldilocks dilemma: Big ice, little ice, or "just-right" ice in the Eastern Canadian Arctic. Quat. Sci. Rev. 2002, 21, 33-48. [CrossRef]

41. Skjelvan, I.; Johannessen, T.; Miller, L.A. Interannual variability of $\mathrm{fCO}_{2}$ in the Greenland and Norwegian Seas. Tellus B Chem. Phys. Meteorol. 1999, 51, 477-489. [CrossRef]

42. Stephens, B.B.; Keeling, R.F. The influence of Antarctic sea ice on glacial-interglacial $\mathrm{CO}_{2}$ variations. Nature 2000, 404, 171-174. [CrossRef] [PubMed]

43. Keeling, R.F.; Stephens, B.B. Antarctic sea ice and the control of Pleistocene climate instability. Paleoceanography 2001, 16, 112-131. [CrossRef]

44. Meredith, M.; Sommerkorn, M.; Cassotta, S.; Derksen, C.; Ekaykin, A.; Hollowed, A.; Kofinas, G.; Mackintosh, A.; MelbourneThomas, J.; Muelbert, M.M.C.; et al. Polar Regions. In IPCC Special Report on the Ocean and Cryosphere in a Changing Climate. IPCC Special Report on the Ocean and Cryosphere in a Changing Climate. 2019. Available online: https://www.ipcc.ch/srocc/chapter/ chapter-3-2/ (accessed on 11 November 2020).

45. Jiang, N.; Yan, Q. Evolution of the meridional shift of the subtropical and subpolar westerly jet over the Southern Hemisphere during the past 21,000 years. Quat. Sci. Rev. 2020, 246, 106544. [CrossRef]

46. Liu, Z.; Otto-Bliesner, B.L.; He, F.; Brady, E.C.; Tomas, R.; Clark, P.U.; Carlson, A.E.; Lynch-Stieglitz, J.; Curry, W.; Brook, E.; et al. Transient simulation of last deglaciation with a new mechanism for Bolling-Allerod warming. Science 2009, 325, 310-314. [CrossRef] [PubMed]

47. Gent, P.R.; McWilliams, J.C. Isopycnal Mixing in Ocean Circulation Models. J. Phys. Oceanogr. 1990, 20, 150-155. [CrossRef]

48. Gent, P.R.; Willebrand, J.; McDougall, T.J.; McWilliams, J.C. Parameterizing Eddy-Induced Tracer Transports in Ocean Circulation Models. J. Phys. Oceanogr. 1995, 25, 463-474. [CrossRef]

49. Otto-Bliesner, B.L.; Russell, J.M.; Clark, P.U.; Liu, Z.; Overpeck, J.T.; Konecky, B.; deMenocal, P.; Nicholson, S.E.; He, F.; $\mathrm{Lu}, \mathrm{Z}$. Coherent changes of southeastern equatorial and northern African rainfall during the last deglaciation. Science 2014, 346, 1223-1227. [CrossRef]

50. Liu, Z.Y.; Lu, Z.Y.; Wen, X.Y.; Otto-Bliesner, B.L.; Timmermann, A.; Cobb, K.M. Evolution and forcing mechanisms of El Nino over the past 21,000 years. Nature 2014, 515, 550-553. [CrossRef]

51. Shi, J.; Yan, Q. Evolution of the Asian-African Monsoonal Precipitation over the last 21 kyr and the Associated Dynamic Mechanisms. J. Clim. 2019, 32, 6551-6569. [CrossRef]

52. Buizert, C.; Keisling, B.A.; Box, J.E.; He, F.; Carlson, A.E.; Sinclair, G.; DeConto, R.M. Greenland-Wide Seasonal Temperatures During the Last Deglaciation. Geophys. Res. Lett. 2018, 45, 1905-1914. [CrossRef]

53. He, F.; Shakun, J.D.; Clark, P.U.; Carlson, A.E.; Liu, Z.Y.; Otto-Bliesner, B.L.; Kutzbach, J.E. Northern Hemisphere forcing of Southern Hemisphere climate during the last deglaciation. Nature 2013, 494, 81-85. [CrossRef] [PubMed]

54. Kalnay, E.; Kanamitsu, M.; Kistler, R.; Collins, W.; Deaven, D.; Gandin, L.; Iredell, M.; Saha, S.; White, G.; Woollen, J.; et al. The NCEP/NCAR 40-Year Reanalysis Project. B Am. Meteorol. Soc. 1996, 77, 437-471. [CrossRef]

55. Huang, B.; Banzon, V.F.; Freeman, E.; Lawrimore, J.; Liu, W.; Peterson, T.C.; Smith, T.M.; Thorne, P.W.; Woodruff, S.D.; Zhang, H.-M. Extended Reconstructed Sea Surface Temperature Version 4 (ERSST.v4). Part I: Upgrades and Intercomparisons. J. Clim. 2015, 28, 911-930. [CrossRef]

56. Lowry, D.P.; Golledge, N.R.; Menviel, L.; Bertler, N.A.N. Deglacial evolution of regional Antarctic climate and Southern Ocean conditions in transient climate simulations. Clim. Past 2019, 15, 189-215. [CrossRef]

57. Sarmiento, J.L.; Gruber, N.; Brzezinski, M.A.; Dunne, J.P. High-latitude controls of thermocline nutrients and low latitude biological productivity. Nature 2004, 427, 56-60. [CrossRef]

58. Lea, D.W.; Pak, D.K.; Peterson, L.C.; Hughen, K.A. Synchroneity of tropical and high-latitude Atlantic temperatures over the last glacial termination. Science 2003, 301, 1361-1364. [CrossRef]

59. Placzek, C.; Quade, J.; Patchett, P.J. Geochronology and stratigraphy of late Pleistocene lake cycles on the southern Bolivian Altiplano: Implications for causes of tropical climate change. Geol. Soc. Am. Bull. 2006, 118, 515-532. [CrossRef]

60. Lamy, F.; Kaiser, J.; Arz, H.W.; Hebbeln, D.; Ninnemann, U.; Timm, O.; Timmermann, A.; Toggweiler, J.R. Modulation of the bipolar seesaw in the Southeast Pacific during Termination 1. Earth Planet. Sc. Lett. 2007, 259, 400-413. [CrossRef]

61. Timmermann, A.; Okumura, Y.; An, S.I.; Clement, A.; Dong, B.; Guilyardi, E.; Hu, A.; Jungclaus, J.H.; Renold, M.; Stocker, T.F.; et al. The Influence of a Weakening of the Atlantic Meridional Overturning Circulation on ENSO. J. Clim. 2007, 20, 4899-4919. [CrossRef] 
62. Toggweiler, J.R.; Lea, D.W. Temperature differences between the hemispheres and ice age climate variability. Paleoceanography 2010, 25, PA2212. [CrossRef]

63. Lee, S.-Y.; Chiang, J.C.H.; Matsumoto, K.; Tokos, K.S. Southern Ocean wind response to North Atlantic cooling and the rise in atmospheric $\mathrm{CO}_{2}$ : Modeling perspective and paleoceanographic implications. Paleoceanography 2011, 26, PA1214. [CrossRef]

64. Wyrwoll, K.-H.; Dong, B.; Valdes, P. On the position of southern hemisphere westerlies at the Last Glacial Maximum: An outline of AGCM simulation results and evaluation of their implications. Quat. Sci. Rev. 2000, 19, 881-898. [CrossRef]

65. Otto-Bliesner, B.L.; Brady, E.C.; Clauzet, G.; Tomas, R.; Levis, S.; Kothavala, Z. Last Glacial Maximum and Holocene Climate in CCSM3. J. Clim. 2006, 19, 2526-2544. [CrossRef]

66. Nelson, C.S.; Hendy, I.L.; Neil, H.L.; Hendy, C.H.; Weaver, P.P.E. Last glacial jetting of cold waters through the Subtropical Convergence zone in the Southwest Pacific off eastern New Zealand, and some geological implications. Palaeogeogr. Palaeoclimatol. Palaeoecol. 2000, 156, 103-121. [CrossRef]

67. Carter, L.; Neil, H.L.; McCave, I.N. Glacial to interglacial changes in non-carbonate and carbonate accumulation in the SW Pacific Ocean, New Zealand. Palaeogeogr. Palaeoclimatol. Palaeoecol. 2000, 162, 333-356. [CrossRef]

68. McGlone, M.S. A late Quaternary pollen record from marine core P69, southeastern North Island, New Zealand. New Zeal J. Geol. Geop. 2001, 44, 69-77. [CrossRef]

69. Russell, J.L.; Dixon, K.W.; Gnanadesikan, A.; Stouffer, R.J.; Toggweiler, J.R. The Southern Hemisphere Westerlies in a Warming World: Propping Open the Door to the Deep Ocean. J. Clim. 2006, 19, 6382-6390. [CrossRef]

70. Marchitto, T.M.; Lehman, S.J.; Ortiz, J.D.; Fluckiger, J.; van Geen, A. Marine radiocarbon evidence for the mechanism of deglacial atmospheric $\mathrm{CO}_{2}$ rise. Science 2007, 316, 1456-1459. [CrossRef]

71. Kitoh, A.; Murakami, S.; Koide, H. A simulation of the Last Glacial Maximum with a coupled atmosphere-ocean GCM. Geophys. Res. Lett. 2001, 28, 2221-2224. [CrossRef]

72. Yin, J.H.; Battisti, D.S. The Importance of Tropical Sea Surface Temperature Patterns in Simulations of Last Glacial Maximum Climate. J. Clim. 2001, 14, 565-581. [CrossRef]

73. Barrows, T.T.; Stone, J.O.; Fifield, L.K.; Cresswell, R.G. Late Pleistocene Glaciation of the Kosciuszko Massif, Snowy Mountains, Australia. Quat. Res. 2001, 55, 179-189. [CrossRef]

74. Barrows, T.T.; Stone, J.O.; Fifield, L.K.; Cresswell, R.G. The timing of the Last Glacial Maximum in Australia. Quat. Sci. Rev. 2002, 21, 159-173. [CrossRef]

75. Gersonde, R.; Abelmann, A.; Brathauer, U.; Becquey, S.; Bianchi, C.; Cortese, G.; Grobe, H.; Kuhn, G.; Niebler, H.S.; Segl, M.; et al. Last glacial sea surface temperatures and sea-ice extent in the Southern Ocean (Atlantic-Indian sector): A multiproxy approach. Paleoceanography 2003, 18, 1061. [CrossRef]

76. Wainer, I.; Clauzet, G.; Ledru, M.P.; Brady, E.; Otto-Bliesner, B. Last Glacial Maximum in South America: Paleoclimate proxies and model results. Geophys. Res. Lett. 2005, 32, L08702. [CrossRef]

77. McGee, D.; Broecker, W.S.; Winckler, G. Gustiness: The driver of glacial dustiness? Quat. Sci. Rev. 2010, 29, 2340-2350. [CrossRef]

78. Kohfeld, K.E.; Graham, R.M.; de Boer, A.M.; Sime, L.C.; Wolff, E.W.; Le Quéré, C.; Bopp, L. Southern Hemisphere westerly wind changes during the Last Glacial Maximum: Paleo-data synthesis. Quat. Sci. Rev. 2013, 68, 76-95. [CrossRef]

79. Sime, L.C.; Kohfeld, K.E.; Le Quéré, C.; Wolff, E.W.; de Boer, A.M.; Graham, R.M.; Bopp, L. Southern Hemisphere westerly wind changes during the Last Glacial Maximum: Model-data comparison. Quat. Sci. Rev. 2013, 64, 104-120. [CrossRef]

80. Sime, L.C.; Hodgson, D.; Bracegirdle, T.J.; Allen, C.; Perren, B.; Roberts, S.; de Boer, A.M. Sea ice led to poleward-shifted winds at the Last Glacial Maximum: The influence of state dependency on CMIP5 and PMIP3 models. Clim. Past 2016, 12, $2241-2253$. [CrossRef]

81. Bourassa, M.A.; Gille, S.T.; Bitz, C.; Carlson, D.; Cerovecki, I.; Clayson, C.A.; Cronin, M.F.; Drennan, W.M.; Fairall, C.W.; Hoffman, R.N.; et al. High-Latitude Ocean and Sea Ice Surface Fluxes: Challenges for Climate Research. B Am. Meteorol. Soc. 2013, 94, 403-423. [CrossRef]

82. Adkins, J.F.; McIntyre, K.; Schrag, D.P. The salinity, temperature, and delta18O of the glacial deep ocean. Science 2002, 298, 17691773. [CrossRef] [PubMed]

83. Cronin, M.F.; Sprintall, J. Upper ocean structure: Buoyancy and wind forcing. In Encyclopedia of Ocean Sciences; Steele, J.H., Thorpe, S.A., Turekian, K.K., Eds.; Elsevier: Amsterdam, The Netherlands, 2001; pp. 3219-3227.

84. Jacobs, S.S. Bottom water production and its links with the thermohaline circulation. Antarct. Sci. 2004, 16, 427-437. [CrossRef]

85. Nadeau, L.-P.; Ferrari, R.; Jansen, M.F. Antarctic Sea Ice Control on the Depth of North Atlantic Deep Water. J. Clim. 2019, 32, 2537-2551. [CrossRef]

86. Liu, Z.; Shin, S.; Webb, R.S.; Lewis, W.; Otto-Bliesner, B.L. Atmospheric $\mathrm{CO}_{2}$ forcing on glacial thermohaline circulation and climate. Geophys. Res. Lett. 2005, 32, L02706. [CrossRef]

87. Volker, C.; Kohler, P. Responses of ocean circulation and carbon cycle to changes in the position of the Southern Hemisphere westerlies at Last Glacial Maximum. Paleoceanography 2013, 28, 726-739. [CrossRef]

88. Gersonde, R.; Crosta, X.; Abelmann, A.; Armand, L. Sea-surface temperature and sea ice distribution of the Southern Ocean at the EPILOG Last Glacial Maximum a circum-Antarctic view based on siliceous microfossil records. Quat. Sci. Rev. 2005, 24, 869-896. [CrossRef]

89. Waelbroeck, C.; Paul, A.; Kucera, M. Constraints on the magnitude and patterns of ocean cooling at the Last Glacial Maximum. Nat. Geosci. 2009, 2, 127-132. 
90. Otto-Bliesner, B.L.; Hewitt, C.D.; Marchitto, T.M.; Brady, E.; Abe-Ouchi, A.; Crucifix, M.; Murakami, S.; Weber, S.L. Last Glacial Maximum ocean thermohaline circulation: PMIP2 model intercomparisons and data constraints. Geophys. Res. Lett. 2007, 34, L12706. [CrossRef]

91. Ninnemann, U.S.; Charles, C.D. Changes in the mode of Southern Ocean circulation over the last glacial cycle revealed by foraminiferal stable isotopic variability. Earth Planet Sc. Lett. 2002, 201, 383-396. [CrossRef]

92. Jansen, M.F.; Nadeau, L.-P. The Effect of Southern Ocean Surface Buoyancy Loss on the Deep-Ocean Circulation and Stratification. J. Phys. Oceanogr. 2016, 46, 3455-3470. [CrossRef]

93. Jansen, M.F. Glacial ocean circulation and stratification explained by reduced atmospheric temperature. Proc. Natl. Acad. Sci. USA 2017, 114, 45-50. [CrossRef] [PubMed]

94. Bouttes, N.; Paillard, D.; Roche, D.M. Impact of brine-induced stratification on the glacial carbon cycle. Clim. Past 2010, 6, 575-589. [CrossRef]

95. Curry, W.B.; Oppo, D.W. Glacial water mass geometry and the distribution of $\delta 13 \mathrm{C}$ of $\Sigma \mathrm{CO}_{2}$ in the western Atlantic Ocean. Paleoceanography 2005, 20, PA1017. [CrossRef]

96. Skinner, L.C. Glacial-interglacial atmospheric $\mathrm{CO}_{2}$ change: A possible "standing volume" effect on deep-ocean carbon sequestration. Clim. Past 2009, 5, 537-550. [CrossRef]

97. Makou, M.C.; Oppo, D.W.; Curry, W.B. South Atlantic intermediate water mass geometry for the last glacial maximum from foraminiferal Cd/Ca. Paleoceanography 2010, 25, PA4101. [CrossRef]

98. Siani, G.; Michel, E.; De Pol-Holz, R.; Devries, T.; Lamy, F.; Carel, M.; Isguder, G.; Dewilde, F.; Lourantou, A. Carbon isotope records reveal precise timing of enhanced Southern Ocean upwelling during the last deglaciation. Nat. Commun. 2013, 4, 2758. [CrossRef]

99. Crowley, T.J. North Atlantic Deep Water cools the southern hemisphere. Paleoceanography 1992, 7, 489-497. [CrossRef]

100. Haumann, F.A.; Gruber, N.; Munnich, M.; Frenger, I.; Kern, S. Sea-ice transport driving Southern Ocean salinity and its recent trends. Nature 2016, 537, 89-92. [CrossRef] 